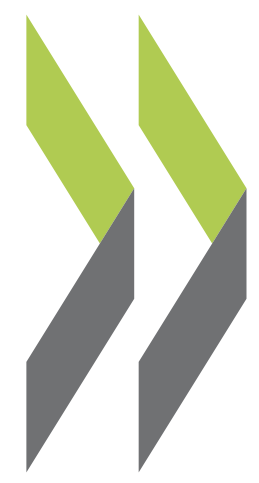

OECD Science, Technology and Industry Working Papers $2002 / 10$

\title{
ICT Skills and Employment
}

\section{Vladimir López-Bassols}


Organisation de Coopération et de Développement Economiques

DIRECTORATE FOR SCIENCE, TECHNOLOGY AND INDUSTRY

STI WORKING PAPERS

\section{ICT SKILLS AND EMPLOYMENT}

Vladimir Lopez-Bassols 


\section{STI Working Paper Series}

The Working Paper series of the OECD Directorate for Science, Technology and Industry is designed to make available to a wider readership selected studies prepared by staff in the Directorate or by outside consultants working on OECD projects. The papers included in the series cover a broad range of issues, of both a technical and policy-analytical nature, in the areas of work of the DSTI. The Working Papers are generally available only in their original language - English or French - with a summary in the other.

Comment on the papers is invited, and should be sent to the Directorate for Science, Technology and Industry, OECD, 2 rue André Pascal, 75775 Paris Cedex 16, France.

The opinions expressed in these papers are the sole responsibility of the author(s) and do not necessarily reflect those of the OECD or of the governments of its Member countries.

http://www.oecd.org/sti/working-papers 
DSTI/DOC(2002)10

\title{
ICT SKILLS AND EMPLOYMENT
}

\author{
Vladimir López-Bassols
}

Given their role in the current transformation of advanced economies, information and communication technologies (ICTs) offer the promise of new business and employment opportunities along with higher productivity gains, but also make new demands on skills. OECD countries are thus confronted with the dual challenge of ensuring that the growth of new industries and activities is not stifled by labour bottlenecks and skill mismatches and that their population is equipped to master the basic IT skills which these transformations require. Despite recent claims of a widespread IT worker shortage, this study argues that although there is indeed some evidence of tightness in labour markets for particular categories of IT workers, the main issue of concern for policy makers and firms should be the gap between the skills of current and future IT workers and those sought by firms.

Both short- and long-term strategies can be implemented to address the rapidly changing skill requirements for ICT jobs. OECD countries appear to be taking similar measures, but they also emphasise the need for better data to measure the IT workforce and for new kinds of partnerships. It is broadly agreed that all stakeholders have a role in implementing short-term solutions and in facilitating mechanisms for devising longer-term strategies. In order to meet changing skill demands in the IT workforce, various supply- and demand-side measures are being deployed. On the supply side, these include providing more information to students, developing stronger IT skills in secondary schools, assisting in teacher training, making IT careers more attractive (in particular to under-represented groups such as women), ensuring better integration of educational programmes with "real world" problems, helping workers maintain up-to-date skills. On the demand and user side, these include better use by employers of the existing workforce (both in terms of recruitment and retention), more information on skill needs and opportunities (including new pathways to IT jobs), adequate training programmes for various categories of workers (including unemployed and older workers), and governments taking a lead role as employers of IT workers.

Immigration is one means of increasing the short-term supply of IT workers. Many countries favour this solution, but immigration alone cannot address the need for cyclical adjustments to the labour market and, by dampening wage growth, it can send conflicting signals to firms, workers and students. 


\title{
COMPÉTENCES ET EMPLOI DANS LE DOMAINE DES TIC
}

\author{
Vladimir López-Bassols
}

Étant donné le rôle joué par les technologies de l'information et des communications (TIC) dans la transformation actuelle des économies avancées, ces technologies apportent la promesse de nouvelles possibilités d'activité et d'emploi, ainsi que d'importants gains de productivité, mais elles imposent aussi de nouvelles exigences en matière de compétences. Les pays de l'OCDE sont actuellement confrontés à la double difficulté de s'assurer que la croissance de nouvelles activités et de nouvelles industries ne soit pas étranglée par les pénuries de main-d'œuvre et l'inadéquation des compétences, tout en faisant en sorte que la population dans son ensemble soit équipée pour maîtriser les compétences de base en TI qu'exigent ces transformations. Malgré les affirmations récentes d'une pénurie massive de main-d'œuvre en TI, cette étude soutient que malgré une certaine tension dans le marché du travail pour des catégories précises de travailleurs des TI, les décideurs politiques devraient plutôt se concentrer sur l'écart entre les compétences de la main-d'œuvre des TI actuelle et future, et les compétences recherchées par les entreprises.

Des stratégies tant à court qu'à long terme peuvent être mises en œuvre pour s'adapter à l'évolution rapide des besoins en compétences dans le domaine des TIC. Les pays de l'OCDE semblent prendre des mesures analogues et insistent sur la nécessité de disposer de données plus fiables pour mesurer les effectifs dans les TI et de constituer de nouvelles formes de partenariat. Il est largement admis que toutes les parties prenantes ont un rôle à jouer tant dans la mise en œuvre de solutions à court terme que dans l'élaboration de mécanismes de conception de stratégies à plus long terme. Face à l'évolution de la demande de compétences de la main-d'œuvre pour les TI, diverses mesures peuvent être prises au niveau de l'offre et de la demande. Du côté de l'offre: fournir plus d'informations aux étudiants, développer davantage les compétences en TI dans l'enseignement secondaire, faciliter la formation de formateurs, rendre plus attrayantes les carrières dans les TI (en particulier auprès de groupes sous-représentés tels que les femmes), mieux rapprocher les programmes éducatifs des problèmes du "monde réel", aider les travailleurs à actualiser leurs compétences. Du côté de la demande et des utilisateurs : mieux utiliser la main-d'œuvre existante (tant en termes de recrutement que de fidélisation), fournir davantage d'informations sur les besoins en compétences et les débouchés (y compris les nouvelles passerelles permettant d'accéder à des emplois de TI), offrir des programmes de formation appropriés à diverses catégories de travailleurs (y compris chômeurs et travailleurs plus âgés) et, pour les pouvoirs publics, montrer l'exemple en tant qu'employeurs de travailleurs des TI.

L'immigration est un moyen d'augmenter l'offre à court terme de travailleurs des TI. Plusieurs pays favorisent cette solution, mais l'immigration ne peut en soi résoudre les problèmes d'ajustement cyclique au marché de l'emploi et, en freinant les augmentations de salaire, risque d'envoyer des signaux contradictoires aux entreprises, aux travailleurs et aux étudiants. 


\section{TABLE OF CONTENTS}

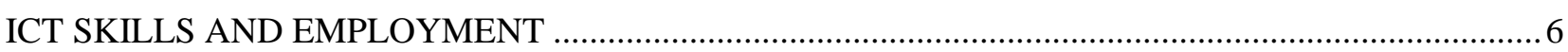

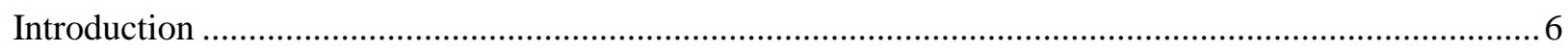

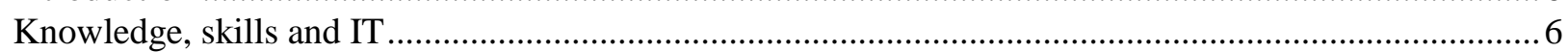

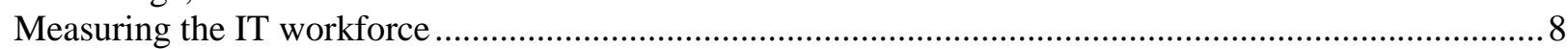

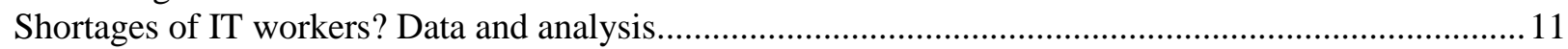

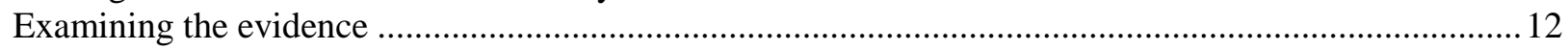

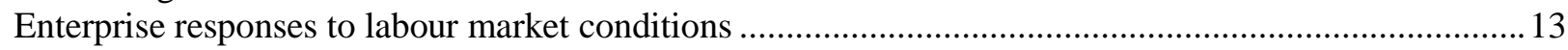

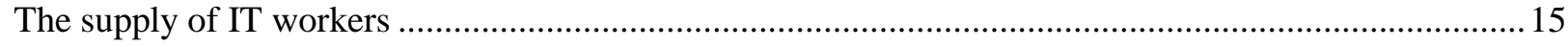

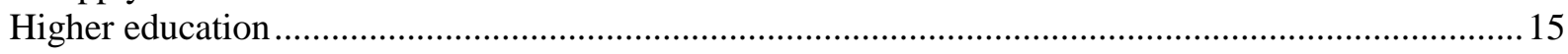

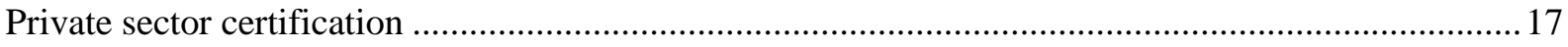

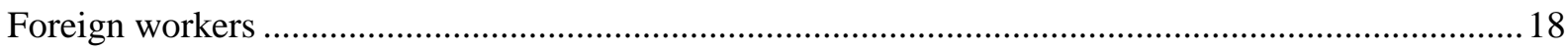

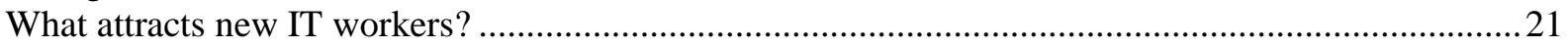

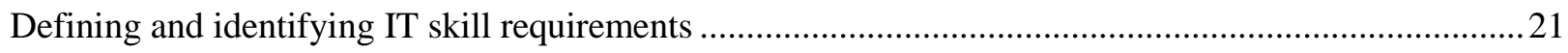

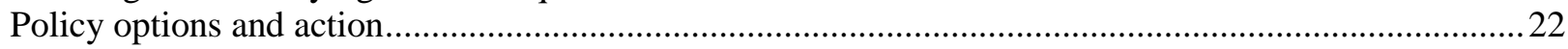

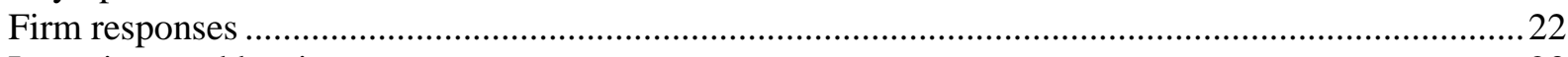

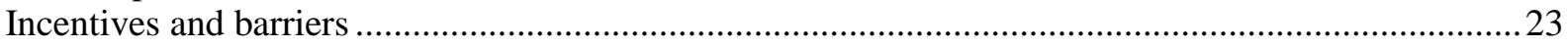

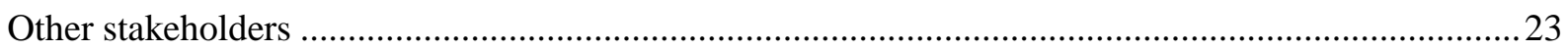

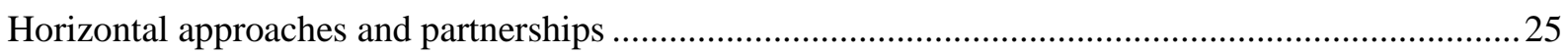

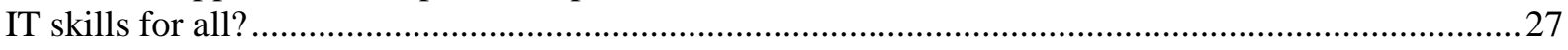

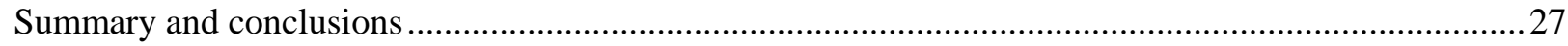

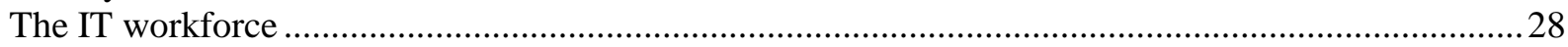

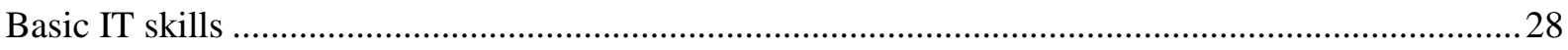

APPENDIX 1: NWCET INFORMATION TECHNOLOGY SKILL STANDARDS .................................32

ANNEX TABLE 1: H-1 VISAS GRANTED IN THE UNITED STATES BY COUNTRY

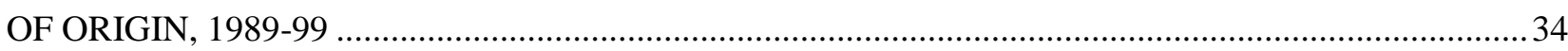

ANNEX TABLE 2: EXAMPLES OF POLICY ACTIONS AND RECOMMENDATIONS

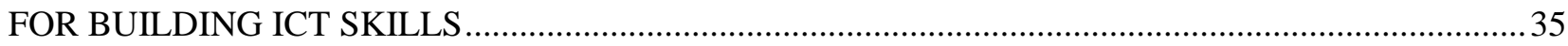

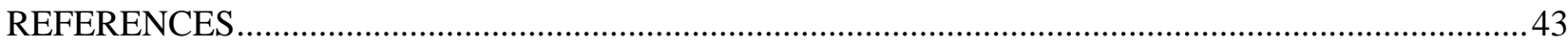




\section{ICT SKILLS AND EMPLOYMENT}

\section{Introduction}

The present study addresses growth and change in the numbers and characteristics of ICT workers and recent concerns about possible skill mismatches in ICT-related jobs (OECD, 2000a). ${ }^{1}$ As ICT employment continues to expand, broad trends are transforming OECD economies and the workforce: the process of globalisation and economic integration has strengthened, structural changes have shifted economic activity (and employment) towards services. Demographic and educational trends (such as ageing populations and rising overall attainment levels) are substantially altering the size and composition of the workforce. Apart from these general trends affecting IT work and IT workers, the rapid growth of new segments of the ICT sector, such as the Internet, e-commerce and IT services, has created new types of jobs requiring new skills (OECD, 1999).

To define the scope of this report, it is necessary to distinguish the characteristics of different IT skill sets. A simple categorisation is:

- Professional IT skills: ability to use advanced IT tools and/or to develop, repair and create them. ${ }^{2}$

- Applied IT skills: ability to apply simple IT tools in general workplace settings (in non-IT jobs).

- Basic IT skills or "IT literacy": ability to use IT for basic tasks and as a tool for learning.

This study focuses on the IT workforce, or those with professional IT skills, and the growing demand for these skills across the economy. It examines the following related questions: Why are IT skills important? Where are IT workers employed? How are firms coping with skill mismatches and tight labour markets? Does immigration play a significant role? It then turns to the issue of IT skills: What are the skill requirements for IT jobs? Can certification schemes help signal IT skills to employers? How is the supply of potential IT workers evolving? Finally, it addresses the roles for different stakeholders when faced with changing skill requirements: What are the relative incentives and barriers for upgrading skills? How might the various economic actors respond if IT skills become a new category of "general" skill?

\section{Knowledge, skills and IT}

As OECD economies continue to move towards "knowledge-based societies", the role of knowledge workers and information workers becomes increasingly crucial (OECD, 2001a). In the 1990s, knowledge workers (including computer workers, along with engineers and applied and social scientists) were the fastest-growing occupational category in the United States and the EU area (Figure 1). Although the links to aggregate growth are difficult to quantify (see Box 1), firm-level evidence suggests a positive association between productivity gains and use of knowledge workers. The sustained growth of new ICT industries and the diffusion of ICTs throughout all sectors have created new skill requirements. However, 
despite the importance of these new skills, there are great conceptual and practical difficulties in attempting to define and measure skills, particularly in fast-moving areas based on information technology.

\section{Figure 1. Employment growth in EU countries and the United States, by occupational group, 1992-99}

Average annual percentage change

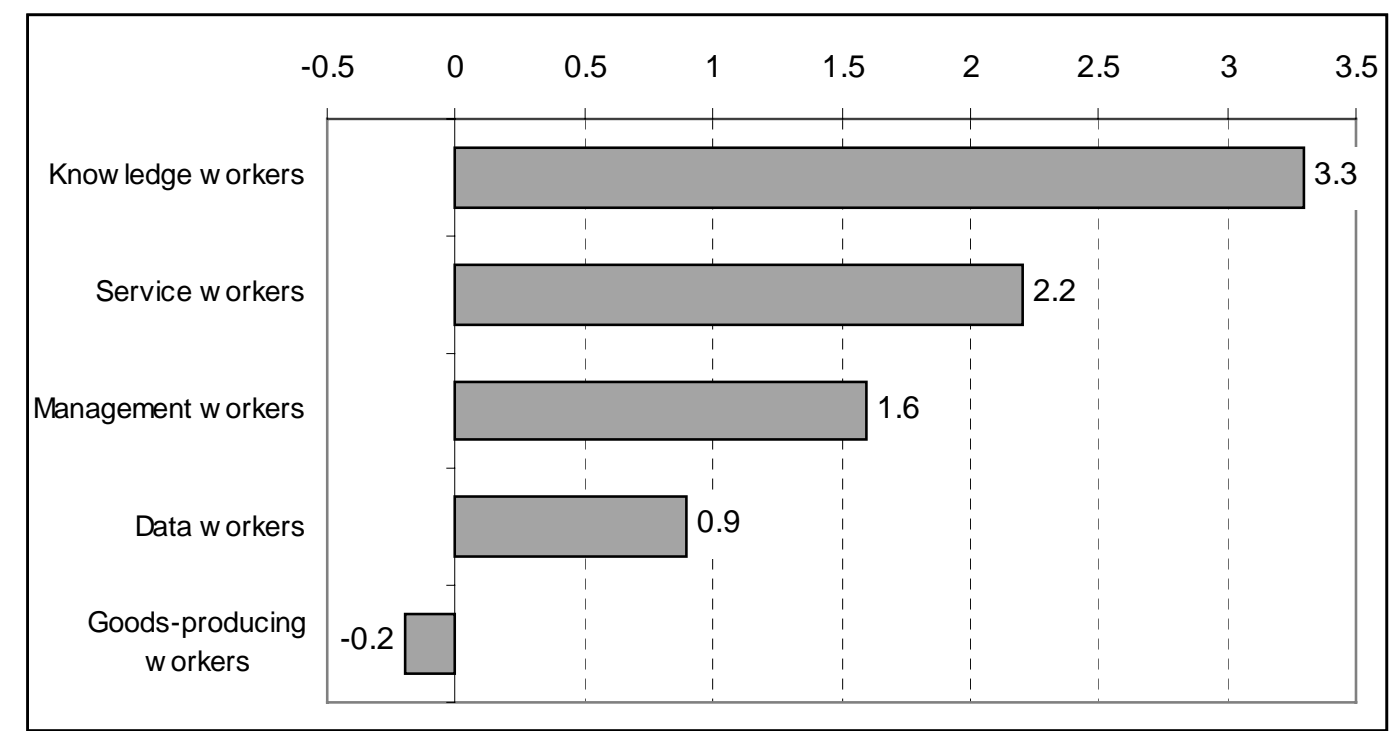

Note: See OECD (2001a) for a complete breakdown by occupational categories. Source: OECD (2001b).

On a basic level, skills refer to the ability to perform tasks, while occupations refer to jobs or work requiring given sets of skills (see OECD, 1998 and ACST, 2000). Skills are important for:

- Individuals: in terms of compensation, employability, personal development.

- Firms: as they allow increases in productivity, competitiveness, adaptability.

- Countries and regions: as determinants of economic growth and social cohesion.

\section{Box 1. Human capital, labour and growth}

Skills and human capital are increasingly regarded as major factors in development and growth. A broad consensus is emerging that there is a positive association between investment in human capital and economic growth (Ahn and Hemmings, 2000; Temple, 2000; OECD, 1998, 2001c). Micro-level studies using regressions on earnings find that schooling often has a significant impact, although it may also act as a signalling/screening/credential device.

Recent analysis of the determinants of economic growth across OECD countries reveals that labour utilisation plays an important role and that strong productivity performance at sectoral level tends to correlate with a general upskilling of the workforce (Scarpetta et al., 2000). In many OECD countries, structural changes have led to higher overall labour utilisation in a context of more productive use of factor inputs. There is still a potential for higher levels of labour utilisation, particularly in continental Europe where employment rates are low, especially among youths, prime-age women and older workers. Labour productivity growth was estimated to account for at least half of the recent GDP growth per capita in most OECD countries.

Compositional changes in the quality of labour input can be measured using educational attainment as a proxy for skills. Scarpetta et al. (2000) found a positive effect from labour composition (skill upgrading) in all countries but Germany for the 1985-98 period. In countries such as the United States, Australia and the Netherlands, skill upgrading seems to have played a modest role, while in others (including most European countries) its role appears to have been more significant. In most OECD countries, there is a general tendency to skill-biased employment growth. 
Although there is growing agreement on the importance of skills per se as a key engine for economic growth and the spread of the knowledge economy, there is far less consensus on which competencies and skills make the difference (OECD, 2001d). Since skills cannot be easily measured, different proxies are used to capture observable characteristics, such as educational attainment on the supply side and occupations on the demand side. As Figure 2 shows, skills are acquired through a variety of channels.

Figure 2. How skills are acquired

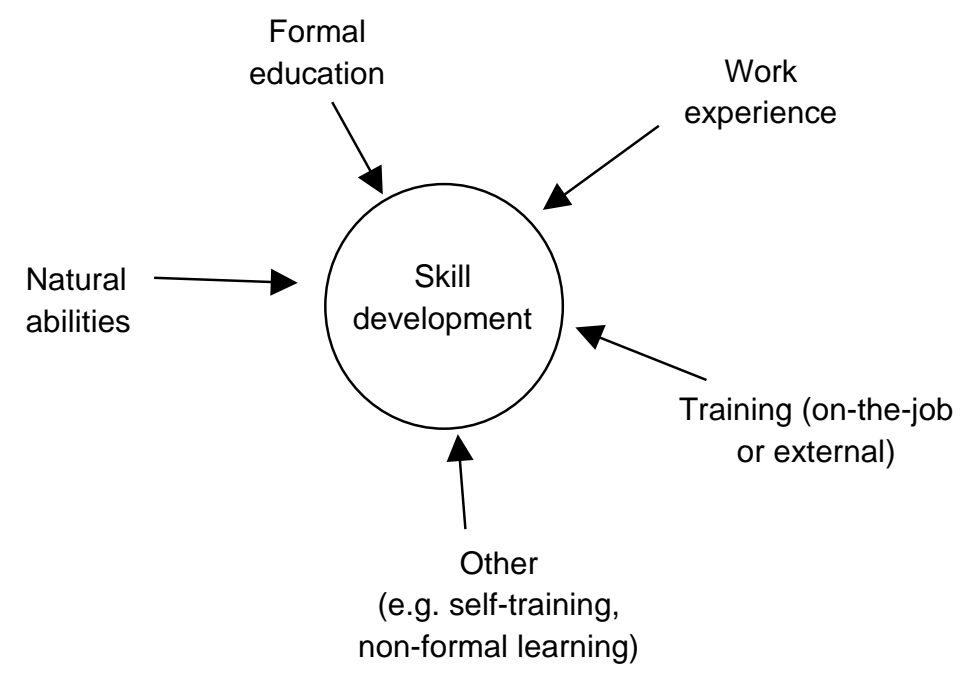

Source: OECD.

By its nature, IT work requires individuals to master codified and tacit knowledge and technical and abstract concepts, which are acquired through various formal (education) and non-formal (work experience) channels. Even for non-IT workers, ICTs are affecting the skills required and the nature and organisation of work (US Council on Competitiveness, 1998; ILO, 2001). Overall, the rapid growth of ICT industries and the wide diffusion of ICTs are radically changing skill sets and occupations, and it is important to gain a better understanding of the employment patterns of this new IT workforce, including new types of compensation, new types of jobs and new motivations. ${ }^{3}$

\section{Measuring the IT workforce}

Industry-based data can provide information on the relative importance of IT-producing sectors in national economies, but are insufficient to capture the true size and nature of the IT workforce. First, not all workers in these industries perform IT-related tasks: many are involved in marketing, sales and various other activities that are not strictly IT-related. Conversely, many IT workers are increasingly employed in sectors other than those producing ICT goods and services: the business and financial service sectors are important employers of IT workers. It is therefore necessary to use other ways of measuring the size and composition of the IT workforce, such as occupational data.

For the United States, Table 1 shows the most recent available data for the entire IT workforce, which reached more than 6.5 million in 2000. It is worth noting that almost $60 \%$ of these workers were employed in high skilled IT occupations (as determined by educational attainment requirements), one-quarter in medium-skilled jobs, and the remaining one-fifth in low-skilled occupations. 
DSTI/DOC(2002)10

Table 1. Employment in IT-related occupations by skill level in the United States, 2000 ('000s)

\begin{tabular}{|c|c|}
\hline Occupation & Employment \\
\hline \multicolumn{2}{|l|}{ High skilled } \\
\hline Computer support specialists & 523 \\
\hline Computer software engineers, applications & 375 \\
\hline Computer systems analysts & 463 \\
\hline Computer programmers & 531 \\
\hline Computer software engineers, systems software & 265 \\
\hline Computer and information systems managers & 283 \\
\hline Network and computer systems administrators & 234 \\
\hline Engineering managers & 242 \\
\hline Electrical and electronic engineering technicians & 245 \\
\hline Network systems and data communications analysts & 119 \\
\hline Database administrators & 108 \\
\hline Electrical engineers & 162 \\
\hline Electronics engineers, except computer & 124 \\
\hline Computer hardware engineers & 64 \\
\hline Computer and information scientists, research & 26 \\
\hline \multicolumn{2}{|l|}{ Medium skilled } \\
\hline Data entry keyers & 459 \\
\hline Electrical and electronic equipment assemblers & 367 \\
\hline Telecommunications line installers and repairers & 168 \\
\hline Computer, ATM, and office machine repairers & 142 \\
\hline Electrical power-line installers and repairers & 96 \\
\hline Telecommunications equipment installers and repairers, exc. line installers & 192 \\
\hline Electrical and electronics repairers, commercial and industrial equipment & 82 \\
\hline Semiconductor processors & 67 \\
\hline Electromechanical equipment assemblers & 73 \\
\hline \multicolumn{2}{|l|}{ Low skilled } \\
\hline Billing and posting clerks and machine operators & 492 \\
\hline Switchboard operators, including answering service & 243 \\
\hline Mail clerks and mail machine operators except postal service & 182 \\
\hline Computer operators & 186 \\
\hline Office machine operators, except computers & 86 \\
\hline Telephone operators & 52 \\
\hline Total IT occupations & 6652 \\
\hline
\end{tabular}

Source: US DOC (2002) based on Bureau of Labor Statistics (BLS), Occupational Employment Statistics (OES) (2002).

The Information Technology Association of America (ITAA) estimates that in 2001 about 10.4 million workers were employed in ICT-related jobs in the United States (all sectors) (ITAA, 2001). Others (NRC, 2001) have questioned this figure owing to the small sample size, the low response rate, ${ }^{4}$ and possible ambiguities in the survey interview questions used to identify IT workers. Nonetheless, this figure may be considered an upper bound for a broad definition of those using IT as a main component of their work. The US Bureau of Labor Statistics estimates that the number of "core" IT workers will grow from 2.2 million in 1998 to 3.9 million in $2008 .^{5}$ Additionally, the United States will need to replace 306000 workers who are leaving these occupations permanently. Accordingly, the United States could require an average of about 201800 new IT workers a year to fill jobs in these occupations. As can be seen, measuring with any precision the size of the IT workforce is a challenging task.

Analysis of occupational data by sector of employment shows that in the United States in 2000, almost two-thirds of all high skilled IT workers (as defined in Table 1) were employed in sectors other than 
computer and data processing services (BLS, 2002). The US Department of Commerce estimates that by 2008, in addition to computer-related services, the following industries will employ more than 100000 IT workers each: wholesale trade, management and public relations, personnel supply services and education (DOC, 2000a).

For the United Kingdom, the most recent analysis of Labour Force Statistics (IES, 2002) estimates that in 2000 , the number of IT jobs (in both IT-producing and IT-using industries) was between 1.1 and 1.3 million, including 940000 in "core" ICT occupations. Of these, just under half were employed in ICTproducing industries.

In Italy, a study conducted by the IT industry association (ASSINFORM et al, 2000) estimated the number of ICT workers at around 890000 in 1999. ${ }^{6}$ It also estimated that a further 122000 workers had (nonprofessional) IT skills.

In Denmark, an analysis of labour force data at the end of 1998 estimated that there were 92900 ICT workers, 60600 of whom were classified as "primary" IT workers. $72 \%$ of these were employed in manufacturing, trade, hotel and restaurant services and business services, while almost $40 \%$ of the "secondary" ICT workers were employed in manufacturing, electricity, gas and water supply (Statistics Denmark, 2001).

Figure 3 shows the share of computer workers ${ }^{7}$ in total employment, which increased steadily during the second half of the 1990s throughout the OECD area (except for a slight decline in Portugal).

\section{Figure 3. Computer workers ${ }^{1}$ as a percentage of total employment in selected OECD} countries/regions, 1995 and 1999

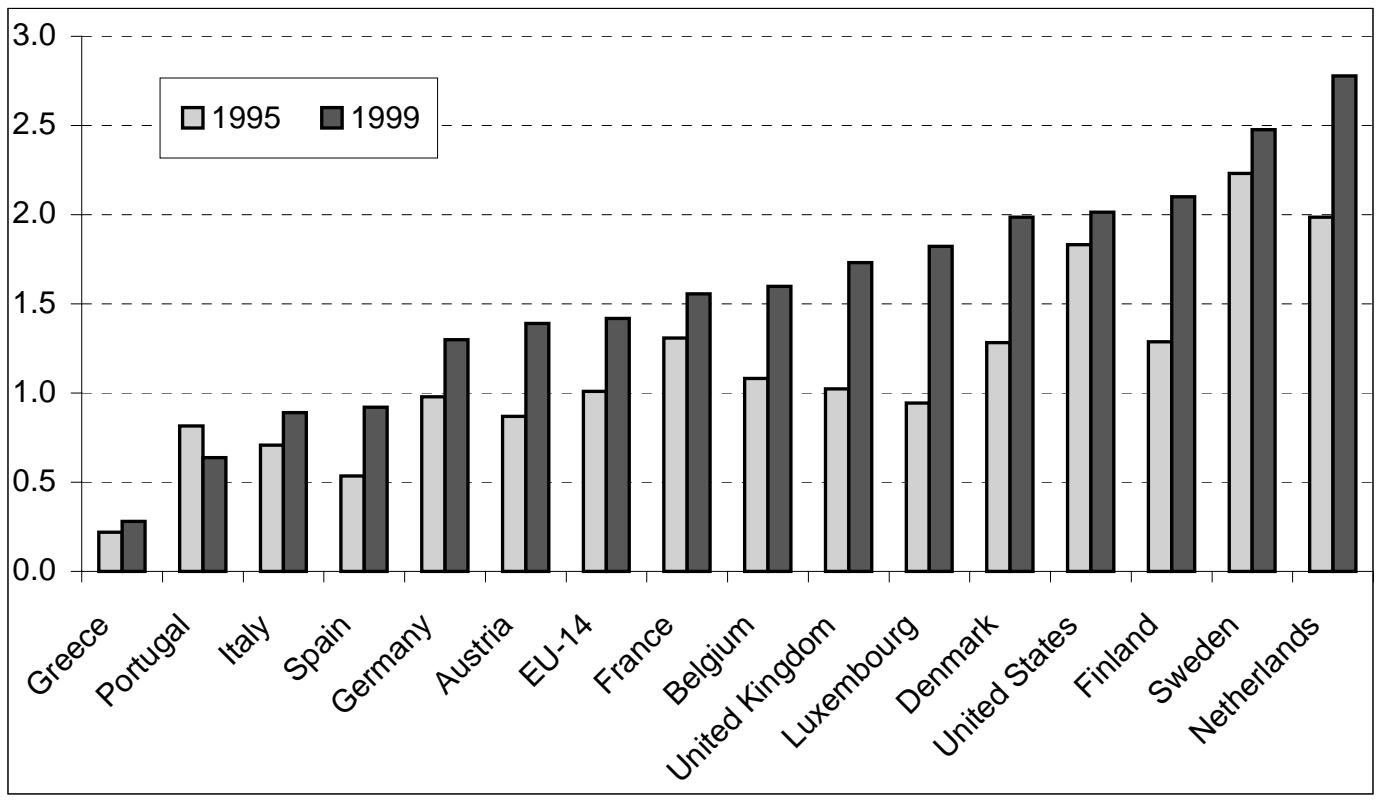

Note: 1995 data estimated for EU-14. 1997 instead of 1995 for Finland and Sweden.

1. For Europe, computer workers include ISCO-88 categories 213 and 312; for the United States, CPS categories 64, 65, 229, 308 and 309.

Source: OECD estimates based on data from the European Labour Force Survey (Eurostat) and the (US) Bureau of Labor Statistics. 
At sub-national level, a recent EU-funded study identified various European regions with a high level of ICT-intensity in term of employment (ISCO occupational categories 213, 312 and 313). In 1999, the Stockholm (Sweden), Paris (France), Utrecht (Netherlands), and Uusimaa (Finland) regions had over 4\% of total employment in ICT occupations (EMERGENCE, 2001).

\section{Shortages of IT workers? Data and analysis}

A labour shortage is usually defined as a persistent shortfall in the supply of qualified personnel at the prevailing wage or salary level. Needless to say, this is often very difficult to quantify. Various private firms and industry associations have produced estimates of jobs required and potential gaps. Many observers have questioned such estimates for the United States while agreeing that there is convincing evidence of tightness in some parts of the IT labour market, particularly in certain new software-related professions (NRC, 2001; DOC, 2000b; Weinstein, 1999; Matloff 1998).

The ITAA estimated a "skills gap" of around 425000 workers in the United States in 2001, or $4 \%$ of the IT workforce (ITAA, 2001). Given the methodology used, these figures must be interpreted with care, ${ }^{8}$ but they do indicate the extent to which specific IT jobs (and related skills) are associated with particularly high demand and continuing concerns regarding supply. The main areas are technical support, database development and administration, programming and software engineering (Figure 4).

Figure 4. Distribution of estimated "IT worker gap" in the United States by activity, 2000

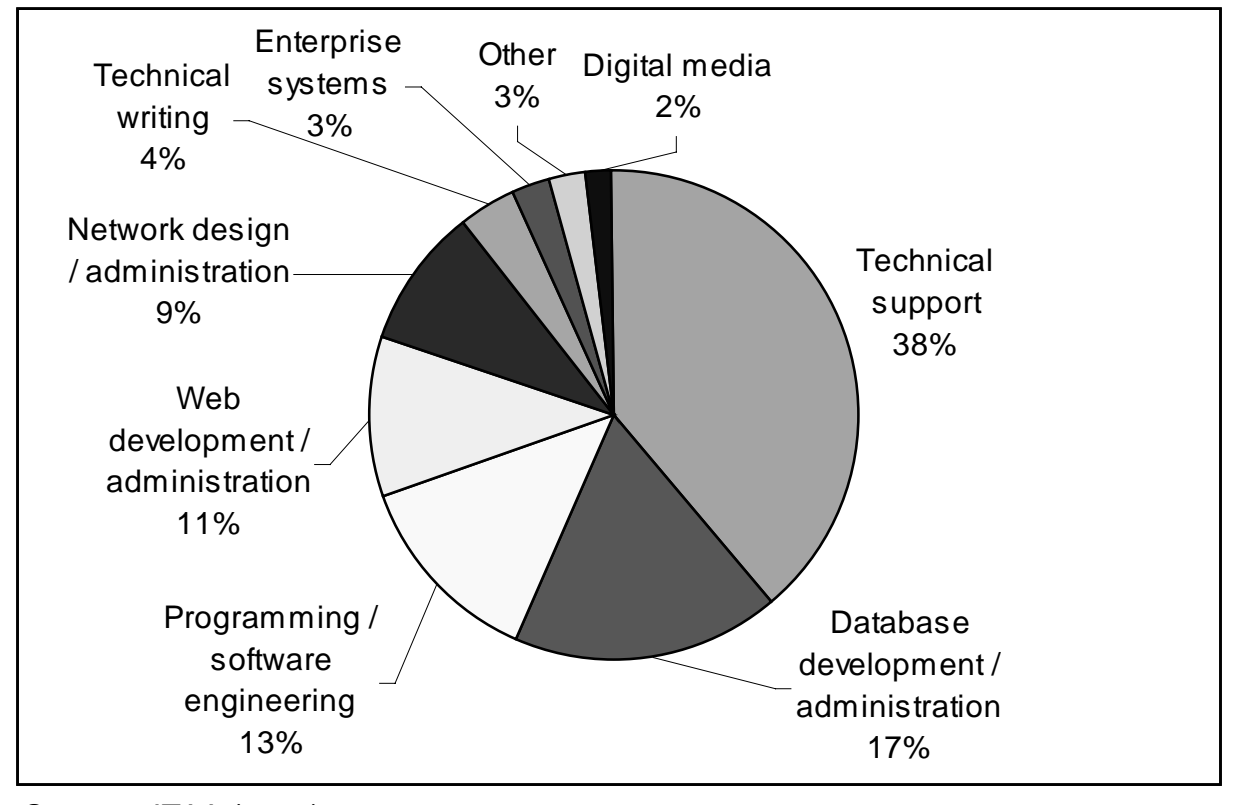

Source: ITAA (2000).

The International Data Corporation (IDC) estimated a demand for 11.2 million IT workers in Europe in 2001, three-quarters of whom with "high-level" (professional) skills (EITO, 2001). In addition, IDC forecasts a demand for 3.9 million workers with "e-business" skills (a combination of technical and business/management skills). This total of more than 15 million workers is then compared to the estimated number of currently available workers, to obtain an estimate of unfilled vacancies (Table 2). IDC expects the demand for IT workers to continue growing rapidly to 13.0 million workers with IT skills and 6.3 million with e-business skills in 2003. It is worth noting that, according to this estimate, the locus of the problem in the next few years will not be an insufficient supply of qualified IT workers, but a mismatch 
due to a growing demand for e-business employees, i.e. those with strong knowledge of IT applications, but not IT professionals per se. In October 1999, the German IT industry association (BITKOM) estimated a need for 75000 jobs in Germany, for the IT-producing industries only (Klotz, 2000).

\section{Table 2. Estimated unfilled vacancies in IT and e-business in Europe, 2001 and 2003} Millions

\begin{tabular}{|c|c|c|}
\hline & 2001 & 2003 \\
\hline IT & 1.36 & 1.69 \\
\hline E-business & 0.87 & 1.98 \\
\hline Total & 2.23 & 3.67 \\
\hline
\end{tabular}

\section{Examining the evidence}

Discussion of IT worker shortages must keep in mind that "economic theory suggests that skill shortages and surpluses are a permanent feature of decentralised labour markets. Hence at any point in time, labour market economists examining the data will find evidence of occupational imbalances" (Roy et al., 1996, in Stager, 1999), but that there will be market responses. Shortages are conceptually difficult to measure; some possible indicators of a tight labour market are strong employment growth, high employment rates for recent graduates, low unemployment rates, strong rise in vacancies ${ }^{9}$ and upward pressure on wages and compensation. Various recent studies have examined the evidence for the United States and concluded that claims of a severe across-the-board shortage are unsubstantiated (NRC, 2001; DOC, 2000b; NSF, 2000a; Ellis and Lowell, 1999a,b,c,d). In addition, the current economic slowdown in the United States and other OECD economies should contribute to ease tensions in the IT labour market as firms adjust to the cycle and reduce staff numbers. ${ }^{10}$

In the United States, employment growth has been strong throughout 2001 and unemployment rates in IT professions remain very low. Earnings continue to increase, but not at a rate consistent with a shortage (except for specific categories of workers in high demand). A factor that may contribute to wage moderation is the increasing number of foreign workers admitted under the $\mathrm{H}-1 \mathrm{~B}$ programme (see the section on foreign workers below). Admittedly, data on wages are not sufficient to adequately describe compensation trends, as different forms of compensation, such as bonuses, profit-sharing schemes and stock options, are increasingly used to attract top workers. Nonetheless, wages are still an important indicator of labour market conditions as these other forms of compensation usually only concern a small share of all IT workers, and the recent plunge of technology-related stock prices has made many of these schemes much less appealing to workers.

On the supply side, many countries appear to have had an upturn in the number of IT-related degrees granted, along with increasing student participation in IT courses, regardless of the field of study (see the section on higher education below).

Overall, although there is high demand in new and rapidly expanding areas, it is not possible to conclude that a severe IT worker shortage exists across all categories of IT jobs. ${ }^{11}$ A distinction should be made between a shortage of IT workers, for which there is little or no aggregate evidence, and a gap between the current skills of IT workers and those sought by firms, for which some anecdotal evidence exists (such as employer surveys). Analysis of the data reveals that indicators of labour market tightness may mask many other problems related to labour market imperfections which are exacerbated by the highly specialised nature of IT jobs. Employers seek specific combinations of (IT and other) skill sets which may not be 
readily found in many otherwise qualified job-seekers. Other problems include inadequate recruitment practices, uncertainty related to temporary work and differences in remuneration (e.g. for IT teachers). Even the growing demand for Internet-related skills may mask a polarisation between highly sought "nextgeneration" skills (e.g. design and management of secure high-speed networks, e-business integration) and the skills needed to perform increasingly routine tasks such as Web site authoring and maintenance (IMIS, 2001).

In Australia, ICT employment increased strongly over the last few years, but vacancies for ICT workers have fallen significantly and employment growth has eased in the past year. ICT employment averaged 214,100 in the 2000-01 financial year, compared with 225,200 in 2001-02. This represents a rise of 5.2\%. However, there are indications that ICT employment will remain subdued in the next year. The average unemployment rate for ICT occupations for the 2000-01 financial year was 2.3\%, but for 2001-02 this had risen to $4.1 \%$. The number of ICT vacancies (as measured by vacancies lodged on five on-line recruiting sites within the past 14 days, and recorded in the DEWR ICT Vacancy Index) peaked in September 2000 and have fallen steadily, by over 80 per cent, to a low in December 2001 (DEWR, 2002). The decline in vacancies appears to have plateaued in the first half of 2002. As at June 2002 there was a slight rise from the previous month of $1.9 \%$, in the ICT Vacancy Index. Other evidence of easing demand for skills and areas of shortage has come from the most recent (April 2002) DEWR Skill Shortage Survey which recorded a vacancy filling rate of nearly $90 \%$ compared with the $60 \%$ in January 2001 . Of approximately 100 specialisations surveyed only a few were identified as being in shortage.

In Canada, wage and other data suggest there is no severe shortage, but that certain skills are in high demand (both technical and business/personal skills) (Gingras and Roy, 1998; ACST, 2000). An analysis of labour force survey data predicted that "there should not be an emerging problem of shortage over the next five to seven years" but also acknowledged the need to improve occupational data and knowledge of current skill requirements at a finer level of disaggregation (Stager, 1999).

In France, professionals ("cadres") in the computer services sector continue to enjoy strong employment growth: 41590 new jobs (+10\%) were created between 1999 and 2000 and $37410(+14.6 \%)$ between 2000 and 2001. This accounts for almost one-quarter of all new professional jobs and more than one-third of all those in service sectors. More than half of the new jobs went to recent graduates. Employment growth has remained strong in communication equipment but much more modest (and even negative during 2000/2001) in IT manufacturing activities. Altogether, growth in ICT jobs is slowing down from previous years but remains strong (APEC, 2001; APEC 2002). Although the ratio of job offers to job seekers in computer-related occupations increased rapidly between 1996 and 1998 (to twice the average for all occupations), there appears to be a slowdown since early 1999 (Ministère du Travail, 2000).

\section{Enterprise responses to labour market conditions}

Employers can opt for either internal or external strategies to address tightness in the labour market ${ }^{12}$ (Table 3). Internal strategies imply using the existing workforce in more effective and productive ways. External strategies imply expanding the pool of potential employees and either attracting new recruits or using external workers. A distinction should also be made between short-term solutions which firms can adopt to address immediate labour requirements and longer-term remedies related to changes in supply. Within medium-/long-term solutions, firms can also focus on two complementary aspects: retaining (and training) their current workforce or attracting new skilled workers. 
Table 3. Firm strategies for coping with skills shortages

\begin{tabular}{|l|l|l|}
\hline & \multicolumn{1}{|c|}{ Short-term } & \multicolumn{1}{|c|}{ Medium-/long-term } \\
\hline $\begin{array}{l}\text { Internal } \\
\text { strategies }\end{array}$ & $\begin{array}{l}\text { Train (or retrain) existing staff } \\
\text { Overtime } \\
\text { Increase wages or other forms of } \\
\text { compensation (profit-sharing, stock options) to } \\
\text { retain current skilled workers } \\
\text { Offer better non-wage benefits (flexible work } \\
\text { schedule, holidays, health benefits and } \\
\text { services) to retain workers }\end{array}$ & $\begin{array}{l}\text { Train (or retrain) existing staff } \\
\text { Changes in management practices and workplace } \\
\text { organisation }\end{array}$ \\
\hline $\begin{array}{l}\text { External } \\
\text { strategies }\end{array}$ & $\begin{array}{l}\text { Outsourcing } \\
\text { Hire foreign workers (either offshore, or } \\
\text { immigrants) } \\
\text { Temporarily hire less skilled workers }\end{array}$ & $\begin{array}{l}\text { Outsourcing } \\
\text { Increase compensation and non-wage benefits to attract } \\
\text { workers, either unemployed or employed by other firms } \\
\text { Expand scope of recruiting: use private recruitment firms, } \\
\text { campus recruiting, Internet recruiting } \\
\text { Work with educational institutions to identify and build } \\
\text { skills for the future }\end{array}$ \\
\hline
\end{tabular}

Firms adopt different strategies, depending on costs and benefits, which differ according to the type of skills required (DOC, 1999; Wilson, 2000; ASSINFORM et al., 2000). For example, the demand for technical support specialists (the category identified in the ITAA survey as the one for which the most unfilled vacancies exist) might be better addressed through outsourcing, than the demand for database specialists (which could be more easily addressed through training). The ITAA study finds that in the United States, outsourcing is the strategy most commonly used by firms to fill vacant IT positions (ITAA, 2000). Another recent US study argues that although firms face important human resource challenges with respect to supply (due to lags in labour market adjustments), the most critical of these stem from managing workers inside companies, including reducing turnover and improving recruitment practices (Cappelli, 2000).

Turnover rates of IT workers in the United States have been particularly high, especially for younger workers (NRC, 2001). On the one hand, if turnover is indeed high, this may have adverse effects on the willingness of firms to train. On the other hand, rapid turnover may also have positive spillovers, as workers learn a variety of new (and marketable) skills when moving to different jobs. The evidence of rapid turnover must be examined in the context of changing expectations of recent graduates and their desire to build experience by moving from job to job. Various McKinsey surveys of computer science and engineering graduates in the United States show that in the early 1990s fewer than one-third expected to stay more than six years with their first employer, compared to almost one-half of those graduating in the 1970s and 1980s (Figure 5) and almost two-thirds of those graduating earlier. Among more recent graduates (1994-96), 47\% expected to spend less than two years with their first employer (Business 2.0, 2000). 
Figure 5. Expected duration with first employer by year of graduation

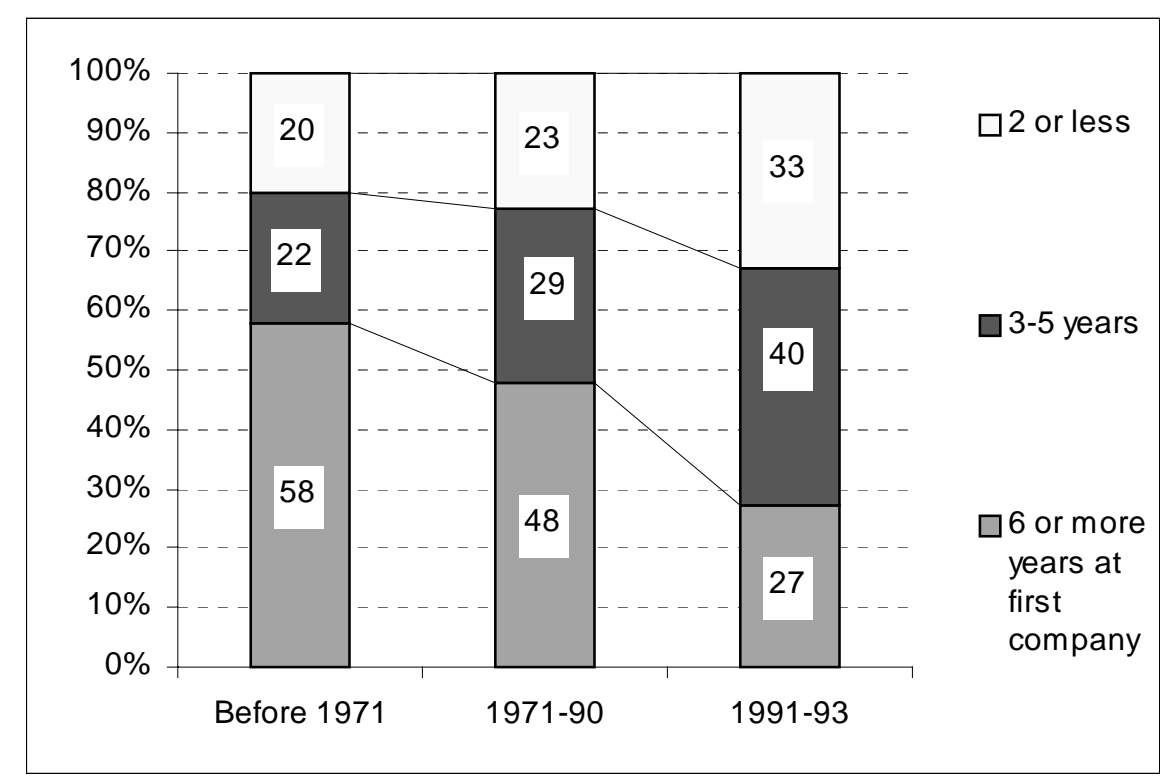

Source: McKinsey in Business 2.0 (2000).

\section{The supply of IT workers}

\section{Higher education}

The main source of IT workers continues to be tertiary-level education. Data from the US Current Population Survey (CPS) show that $60.2 \%$ of all computer programmers held a bachelor's degree or higher in 2000 , while an additional $11 \%$ held an associate's degree. In the case of computer systems analysts, the figures were $69.8 \%$ and $9.1 \%$, respectively. Figure 6 shows the ratio of computer science tertiary-level graduates to those in other fields of study, which averaged 2.9\% in the OECD area in 1999. Data from the US Department of Education show that in 1997-98 computer and information sciences accounted for 2.4\% of all bachelor's and master's degrees granted, up from $2.2 \%$ in the mid-1990s, but a full percentage point lower than in the late 1980s (NCES, 2001). 
Figure 6. Computing in tertiary education in OECD countries, 1999 Tertiary-level graduates in computing as a percentage of all fields of study

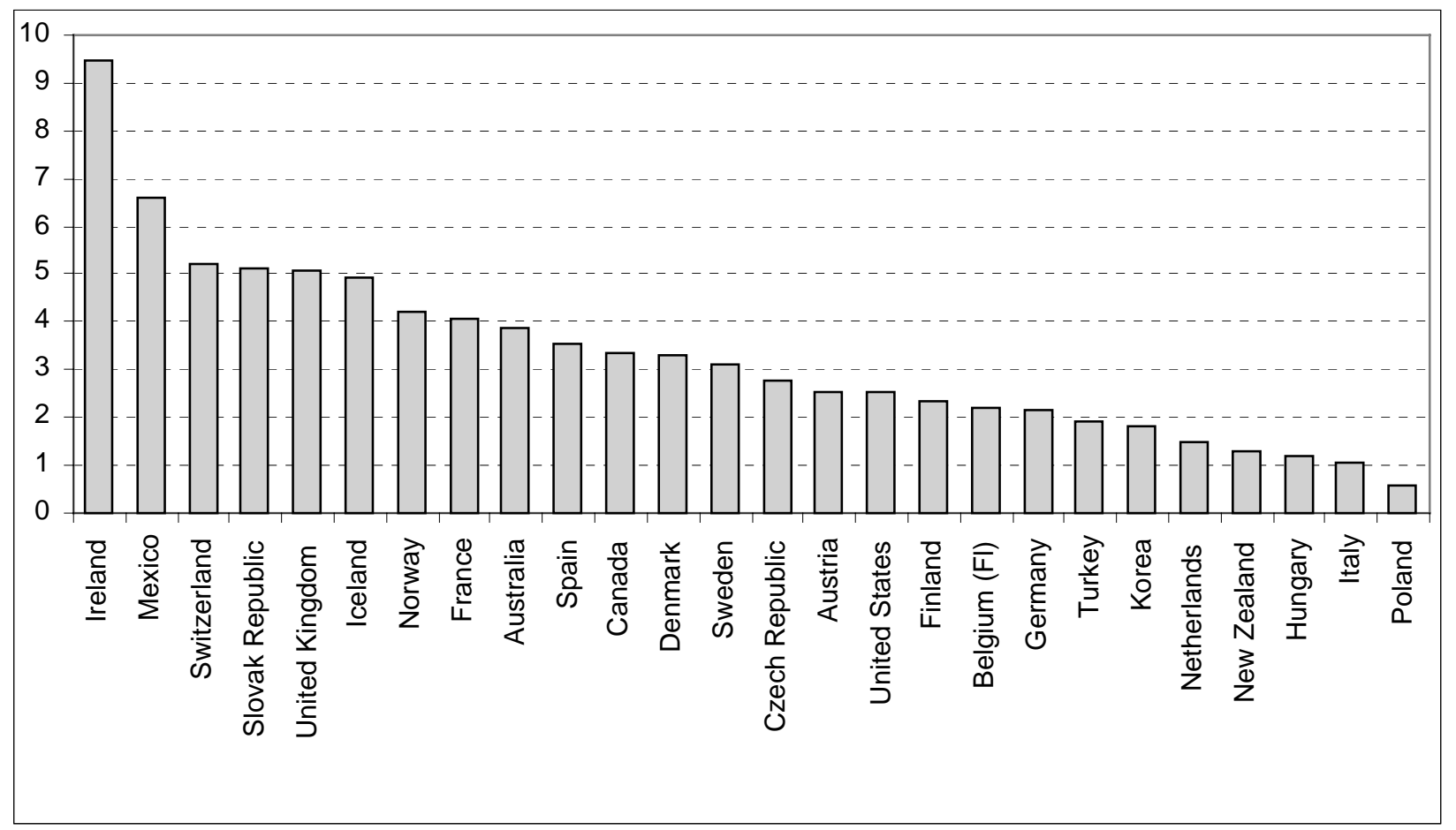

Source: OECD Education Database, May 2001.

There is recent evidence of sustained increases in the supply of IT graduates. The Taulbee Survey covers $\mathrm{PhD}$-granting departments of computer science and computer engineering in the United States and Canada (CRA, 2000 and 2001) and provides data broken down by type of degree. ${ }^{13}$ Results from the latest survey show that the number of bachelor's degrees awarded was projected to grow from around 8000 in 1997 to almost 16000 (estimated) in 2001. There has also been significant growth in the number of master's degrees, with a 19\% increase between 1999 and 2000. On the other hand, there has been an observable slowdown in the growth of PhDs since the mid-1990s, partly owing to changes in the labour market as job prospects are currently very positive for holders of master's degrees. In the United Kingdom, the number of graduates in computer science has increased by $25 \%$ since 1995 and is currently just over 10000 (IES, 2002). If other ICT-related fields are included (i.e. mathematics, electrical and electronic engineering, etc.), the figure reaches 65000 .

Post-secondary education is the main supplier of workers entering IT jobs, nonetheless graduates in computer science and engineering are only a part of all individuals eventually pursuing IT careers. US data for 1997 reveal that among "core" IT workers, 46\% had IT degrees (BA or higher, including minors or second majors), $14 \%$ engineering (other than computer), $26 \%$ science and maths and $6 \%$ business (US DOC, 1999).

In the United Kingdom, the share of IT workers with an IT degree increased slightly from 33\% in 1994 to $37 \%$ in 1998. Among ICT workers, software engineers have, on average, the highest academic degrees: in 2000 almost $60 \%$ held a first degree or higher (IES, 2002). However, two-thirds of IT workers do not have IT degrees, and two-thirds of IT graduates do not work in IT jobs (AISS/ITNTO, 1999). Similar results from Statistics Denmark (2001) confirm that there is no systematic link between ICT education and ICT occupations: almost half of those employed in ICT jobs do not have formal ICT education degrees. Likewise, more than half of those with formal ICT education work in non-ICT jobs. 
As Box 2 shows, women are usually underrepresented, even when compared to other science and engineering fields. By enhancing the attractiveness of this career, governments and firms could help to expand the pool of potential IT workers.

\section{Box 2. IT degrees and gender}

Data on tertiary-level graduates highlight a gender imbalance: computing continues to be a field of tertiary-level study that attracts a disproportionate share of men. In 1999, in four-fifths of OECD countries, men accounted for over $80 \%$ of tertiary-level computing degrees.

A UK study estimates that in 1997 women accounted for only $17 \%$ of entrants to computer science higher education courses, compared to $53 \%$ for all fields of study (IES, 2002).

In the United States in 1997-98, women accounted for only $26.7 \%$ of bachelor's degrees in computer and information sciences and 29.0\% of all master's degrees (NCES, 2001). Between 1980 and 1997, one-quarter of all graduate students in computer science in the United States were women, compared to one-third for all science and engineering fields (NSF, 2000b).

In Sweden, of the 43000 graduates from higher education IT programmes from 1977/78 to 1998/99, just over a quarter were women. For the latest year available, the share was $28 \%$ after a decline during the mid-1990s (Swedish Ministry of Industry, Employment and Communications, 2000a).

In Norway, the Norwegian University of Science and Technology (NTNU) introduced in 1997 a special quota system for women in computer technology studies. The project soon produced positive results. In the first two years, the percentage of female students increased to more than $30 \%$. In addition, the Government has carried into effect several initiatives to increase the number of female pupils and students taking up IT and technology-related skills. Finally "ICT Norway", the largest IT-organisation in Norway initiated in 2002 a special mentor-program to increase the number of women in the IT-sector, titled "OD@”.

\section{Private sector certification}

In the last few years, there has been a strong increase in the number of technical credentials granted by companies, business associations and commercial IT bodies. Table 4 shows that by early 2000, Cisco, Microsoft, Novell and other firms or private bodies had awarded more than 1.8 million credentials ${ }^{14}$ certifying IT skills to individuals.

Table 4. World-wide commercial IT certifications, early 2000

\begin{tabular}{lr}
\hline & Certifications \\
\cline { 2 - 2 } Microsoft Certified Professional (MCP) & 457603 \\
Microsoft Certified Solutions Developer (MCSD) & 23785 \\
Microsoft Certified Systems Engineer (MCSE) & 231180 \\
Other Microsoft Certified Professional Programmes & 176028 \\
Certified Cisco Design Associate (CCDA) & 4000 \\
Other Cisco certifications & 31000 \\
Certified Novell Engineer (CNE) & 175000 \\
Certified Novell Administrator (CNA) & 370000 \\
Other Novell Certifications & 18300 \\
Oracle (all certifications) & 24000 \\
CISSP (Certified Info Systems Security Professional) & 1500 \\
CCA (Citrix Certified Associate) & 8000 \\
A+ (Computer Tech Industry Associate) & 180000 \\
Institute for Certification of Computing Professionals & 50000 \\
Natl. Assoc. of Communication Systems Engineers (all Certif.) & 18000 \\
Others (Baan, Sybase, SAP, Adobe, etc.) & 43778 \\
Total & 1812174 \\
\hline Source: Adelman (2000) and 21st Century Workforce Commission (2000).
\end{tabular}

Source: Adelman (2000) and 21st Century Workforce Commission (2000). 
There is still insufficient information on the exact role played by such certification programmes in terms of IT employment. Analysis of recent vacancy data underscores the growing role of these tools (and provides an interesting corollary to IT worker shortage estimates based on vacancies). Around one in seven positions advertised in the United States was found to require a commercial certification (Adelman, 2000). Further analysis could include identifying the types of workers undergoing certification and examining the incentives for workers (or firms) to pay for such programmes. These programmes should also be linked to broader attempts to recognise, certify and accredit different forms of non-formal learning. ${ }^{15}$

\section{Foreign workers}

Foreign workers are an important source of labour and play an increasingly important role in the context of tight national labour markets for IT specialists. The two main categories are immigrants (both temporary and permanent) and offshore workers. ${ }^{16}$ Although foreigners can help alleviate problems related to strong labour demand during economic upturns, immigration alone cannot resolve the need for cyclical adjustments to the labour market (OECD 2001e). In the case of occupations or skills in high demand (such as ICT) five main types of measures are being taken to facilitate the admission of foreign specialists (OECD, 2001f, Chapter 5):

- Relaxing quantitative constraints (e.g. United States).

- Setting up special inward migration programmes for occupations with shortages (e.g. Germany, Canada, Australia).

- Facilitating recruitment conditions or procedures and relaxing criteria for issuing employment visas for highly skilled workers (e.g. Australia, Canada, France, Japan, New Zealand, Norway, United Kingdom).

- Increasing non-wage incentives for skilled foreign workers (e.g. Australia).

- Allowing foreign students to change status at the end of their studies (e.g. Germany, Switzerland, Australia, United States).

In the United States, the H-1B visa programme aims to attract skilled non-immigrant workers. Although the programme is not restricted to IT workers, more than half of the petitions currently granted are issued to workers in computer-related occupations (INS, 2000a). ${ }^{17}$ The number of such visas has increased from 65000 per year prior to 1998, to 115000 and then to 195000 (from FY2001 to 2003). These temporary visas are valid for six years, and must be renewed after the first three. Although there are no country quotas under this programme, recent data show that about half of all visas are granted to workers from India, followed by China and Canada (Figure 7 and Annex Table 1). It was recently estimated that the H-1B population in the United States is around 425000 and that about one-quarter of these visa-holders have changed from foreign student status (F visa) (Lowell, 2000). Foreign-born individuals (both temporary and permanent immigrants) accounted for about $17 \%$ of the US IT workforce, compared to $10 \%$ for the overall population (NRC, 2001). 
Figure 7. Geographical distribution of H-1B petitions approved by the INS between October 1999 and February 2000, by country of origin

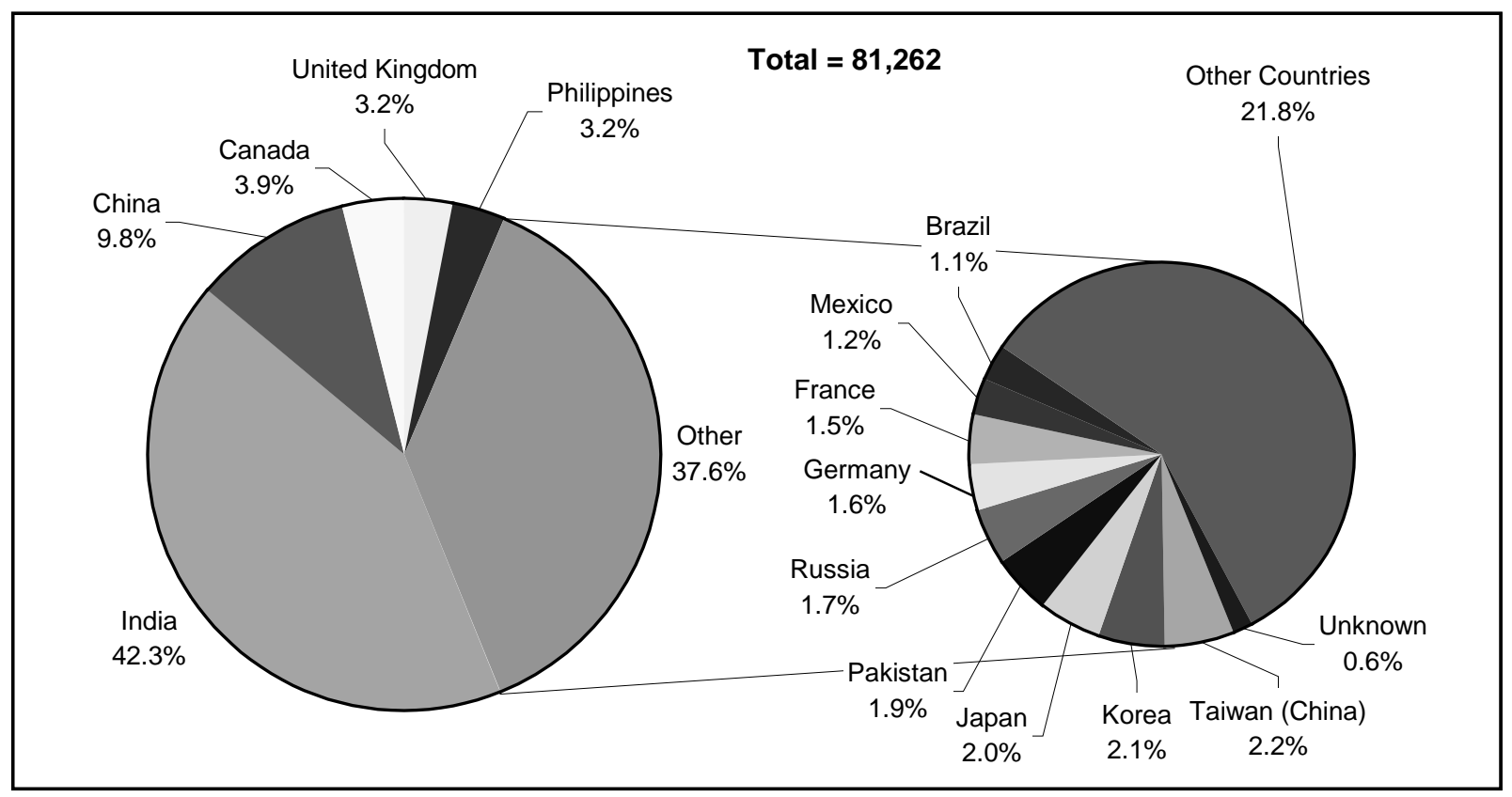

Source: INS (2000a).

Table 5 presents recent data on the firms employing workers with $\mathrm{H}-1 \mathrm{~B}$ visas and shows that, in addition to the largest hardware and software companies, firms with strong ties to India such as Syntel Inc., Wipro Ltd. and Tata Consultancy Services are among the main recruiters. ${ }^{18}$

Table 5. Leading employers of $\mathrm{H}-1 \mathrm{~B}$ visa holders, petitions approved by the INS between October 1999 and February 2000

\begin{tabular}{lr}
\hline Company & Number \\
\hline Motorola & 618 \\
Oracle Corp. & 455 \\
Cisco Systems Inc. & 398 \\
Mastech (iGATE Capital) & 389 \\
Intel Corp. & 367 \\
Microsoft Corp. & 362 \\
Rapidigm & 357 \\
Syntel Inc. & 337 \\
Wipro Ltd & 327 \\
Tata Consultancy Services. & 320 \\
\hline Source: INS (2000b). &
\end{tabular}


DSTI/DOC(2002)10

Box 3 describes several programmes for foreign ICT workers in OECD countries. ${ }^{19}$

\section{Box 3. Foreign ICT worker programmes in various OECD countries}

\section{Germany}

In August 2000, Germany launched a "Green Card" programme that allows for 20000 temporary visas to be issued to computer specialists from outside western Europe. An analysis of the data ${ }^{20}$ for the first 8.5 months of the programme shows that the main source of workers are eastern European countries (around 40\%), followed by India and Pakistan (about one-fifth). Most are men (88\%) and are hired from abroad (about 85\%), except for North Africans, who are predominantly hired after study in Germany. Although there are two criteria for eligibility - educational attainment and income - the former is determining in almost $90 \%$ of cases. Around two-thirds of these workers are employed in small firms (fewer than 100 employees). Eight months after the programme's inception only one-third of the 20000 cards had been allotted.

Canada

In terms of IT workers, Canada faces both immigration and emigration issues. Despite a perceived gap in employment opportunities and income tax differentials, there seems to be no evidence of an increasing "brain drain" towards the United States. The net effect is in fact estimated to be positive, as a growing number of foreign workers are moving to Canada (Helliwell, 1999). A recent study of Asian computer professionals hired by Canadian firms shows that effective recruitment and retention strategies are needed given the global nature of competition for skilled workers (CPRN, 2001).

Australia/New Zealand

As a result of strong employer demand for ICT skills in 2000-01, Australia experienced an estimated net gain of approximately 9200 ICT workers through its permanent migration and temporary entry programs and returning residents. This was a 90 per cent increase on 1999-00, which totalled some 4800 ICT workers. Current trends indicate that the number of ICT workers entering Australia on a temporary basis in 2001-02 is declining as market forces take effect following rationalisation and downsizing in the global and local ICT workforce. The number of ICT positions approved under the Temporary Business (Long Stay) visa decreased by 12.5 per cent from 6749 in 2000-01 to an estimated 5900 this program year.

There remains strong demand for permanent migration from skilled ICT workers and overseas students graduating from Australian universities with ICT qualifications. Given this, it is expected that there will be an increase in the net gain of ICT workers on the 2000-01 figure

The New Zealand Immigration Service announced that it would start pilot testing on-line applications for visas and permits in order to attract IT talent. ${ }^{21}$

United Kingdom

Of the 42000 work permits granted in 1999 to non-EU nationals, 2000 went to immigrants employed in ICT occupations. Of these, two-thirds were from India, and the remainder were mainly from English-speaking countries (IES, 2002). A "fast-track" work permit system has since been implemented to speed up the recruitment of foreign workers by companies experiencing skills shortages. In addition, certain ICT occupations have been added to the "shortage occupation list", and other measures have been taken to attract workers from Asia and Eastern Europe, as well as extending the period of stay from four to five years (OECD, 2001f).

Norway

In March 2001, the Norwegian government launched a programme to amend regulations in order to simplify the recruitment of skilled workers and specialists from countries outside the EEA area. With the amended regulations, the processing time of applications will be reduced, and a non-EEA citizen will be able to obtain a work permit more rapidly than before. The regulations entered into force in January 2002.

Source: OECD and other sources as cited. 


\section{What attracts new IT workers?}

Smaller and younger companies are becoming increasingly attractive to young graduates. According to a McKinsey survey in the United States, more than two-thirds get their first job with a large company (more than 1000 employees), but small firms (fewer than 500 employees) are preferred once employees move to a second job.

New non-standard forms of compensation such as stock options and performance-related bonuses are strong incentives for talented workers (Hoch et al., 2000). Given high turnover rates, firms are often willing to offer high non-standard compensation packages to retain and attract the most skilled workers (Table 6). Although earnings through such schemes have been growing at a much faster rate than wages, these incentives only appear to benefit a small proportion of all IT workers.

Table 6. Annual growth in compensation for workers in software firms in the United States, 1997-99

\begin{tabular}{lrrrrr}
\hline & Base salary & Cash awards & $\begin{array}{c}\text { Long-term } \\
\text { incentives }\end{array}$ & $\begin{array}{c}\text { Total } \\
\text { compensation }\end{array}$ & $\begin{array}{c}\text { Number of incumbents } \\
(1999)\end{array}$ \\
\cline { 2 - 6 } Technical staff & $5.12 \%$ & $15.85 \%$ & $36.79 \%$ & $7.15 \%$ & 35022 \\
Managerial jobs & $6.76 \%$ & $32.28 \%$ & $95.77 \%$ & $24.95 \%$ & 5339 \\
\hline
\end{tabular}

Source: Executive Alliance in NRC (2001).

Given the relative job security and job opportunities that they enjoy, IT workers can often afford to ask for other benefits besides, or in addition to, financial compensation. An international survey of software firms identifies individual workplace styles as strong incentives for workers seeking jobs (Hoch et al., 2000). A McKinsey survey highlights other non-monetary incentives that prospective employees value highly: autonomy, lifestyle, company culture, geographic location (Business 2.0,2000). Some observers have even argued that a new class of "digital nomads" is emerging: highly skilled and mobile workers with little or no attachments to firms or countries (Makimoto and Manners, 1997).

\section{Defining and identifying IT skill requirements}

Surveys from countries such as the United States (NRC, 2001; ITAA, 2000), Canada (ACST, 2000; Sangster, 1999), Ireland (ISC, 2000 $a$ and 2000b; Forfás, 2000a and 2000b), and the United Kingdom (AISS/ITNTO, 1999; Hendry 1999; DfEE 2000 $a$ and 2000b) concur with the finding that IT firms tend to seek a combination of three main types of skills: ${ }^{22}$

- Technical skills: primarily IT, but also quantitative analysis/data modelling, digital media, technical writing, etc.

- Business/management skills: in particular marketing, strategy and business writing.

- Personal skills: communication, leadership, teamwork, problem-solving ability.

Along with the emergence of new occupations, new jobs are appearing which require hybrid skills (Ducatel and Burgelman, 2000). Content industries are an example of activities where interdisciplinary work calls for a combination of creative and technical skills, as well as business abilities.

Data based on industrial and occupational classifications do not provide sufficient information on the specific skills of the IT workforce. Given that IT workers undertake a wide range of activities that fall 
under different occupational categories (not always IT-related), more detailed tools are needed to identify IT jobs and the specific skills required. Appendix 1 contains a detailed list of IT-related occupations from the US Northwest Center for Emerging Technologies (NWCET), divided into eight clusters. These standards cover technical skills, employability skills and basic knowledge requirements for each IT career cluster. Each cluster has a range of jobs at various levels.

In the United Kingdom a Skills Framework for the Information Age (SFIA) has been developed by a consortium of public and private bodies along similar lines. It is constructed as a two-dimensional matrix with skills and responsibility levels as the axes. One axis divides ICT activities into skills grouped into subcategories or "business roles". Subcategories are then grouped into six work areas: strategy and planning, management and administration, development and implementation, service delivery, sales and marketing and use. The other axis defines the level of responsibility and accountability exercised by ICT workers and users. Each of seven levels, from new entrant to strategist level, is defined in terms of autonomy, influence, complexity and business skills. A skills/levels matrix can then be used to show which skills are relevant at which levels (ITNTO, 2000). This system is intended as a diagnostic tool to assist employers in determining more precisely and systematically the skill content of current jobs and new skill requirements. It is also meant to help firms to develop training, recruitment and outsourcing policies. The framework is designed in such a way as to be compatible with detailed competence descriptions and other schemes, such as the IT National Occupational Standards, the British Computer Society's Industry Structure Model 3 (ISM3.2) and the NWCET system.

\section{Policy options and action Firm responses}

There is a need to balance costs and benefits for both firms and employees as training generates increased wages for workers, but also increased productivity for firms, especially if introduced in connection with changes in work organisation (OECD, 1996; OECD 1998; Bresnahan et al., 1999). High turnover rates might act as a strong disincentive for firms to invest in generic (not company-specific) skills (IT or other), especially given the rapid pace of change in the industry. On the other hand, the availability of training can be an additional incentive for a worker to accept a job within a certain firm. ${ }^{23}$ In the case of IT training, there is reason to believe that workers will be willing to share some of the costs of training aimed at building and updating highly marketable skills. Many firms have opted for a combination of on-the-job and training outside of normal working hours. ${ }^{24}$

Firms are also establishing closer links with educational institutions. Both through in-house programmes (apprenticeships) $^{25}$ as well as through involvement in formal education (both direct support in terms of equipment and/or human resources and co-operation in designing curricula and academic programmes). Finally, employers can contribute by clarifying which attributes they consider to be essential for IT jobs, and which ones are merely desirable (NRC, 2001).

Industry associations also play an important role in helping identify skill needs of firms. They can act as a bridge with educational institutions and facilitate structured assessment programmes at an industry-wide level. Two examples previously mentioned are the NWCET and SFIA skill setting exercises in which industry associations have played a significant role. The Council of European Professional Informatics Societies (CEPIS) has developed a similar set of standard statements of attributes and skills for ICT jobs (CEPIS, 2001). Given rapid changes in the industry, certification can help firms to quickly identify workers with the latest skills. In Australia the Industry IT\&T (Information Technology \& Telecommunications) Skills Taskforce has played an important role in relaying concerns from private firms to policy makers. In Canada the sector councils (e.g. Software Human Resources Council) play a key role including surveying sectoral skills needs, establishing occupational/skill standards, and developing 
education and training programmes (ACTS, 2000). In the United States, the ITAA has launched a series of Workforce Development Initiatives including organising nation-wide and regional conferences, implementing a programme to engage IT employers in the "School-to-Careers" programme, launching a national internship programme targeting minority students, and assisting in the development of an IT career cluster model (ITAA, 2000). The World Information Technology and Services Alliance, a federation of national industry associations, has recently compiled an extensive inventory of studies and actions undertaken by governments, firms, and other stakeholders (WITSA, 2001).

\section{Incentives and barriers}

A range of different stakeholders are involved in building IT skills, with different incentive structures (costs and benefits) resulting in different human capital investment strategies. Table 7 provides a general framework relating to the main questions: who pays for what and who can expect to appropriate the benefits, keeping in mind that private and social rates of return do not always converge (OECD, 1998). Although there is strong evidence that secondary education yields important social rates of return (strengthening the case for government support), the evidence for tertiary education and training seems to suggest greater relative private rates of return to individuals. This is particularly the case for IT training and work, given a backdrop of favourable employment opportunities and increasing compensation, supporting arguments favouring cost sharing. Although no analysis has been done specifically on IT workers, studies on the broader group of scientists and engineers and other categories of "knowledge workers" suggest that important spillovers exist and that government policy should focus on increasing the supply of such workers instead of targeting demand (Romer, 2000).

The complexity of linkages reinforces the need to develop a systemic approach addressing the various inter-connected parties: schools and higher-education institutions, private firms, government and individuals. Workers and graduates need information on which skills are in demand, as well as on where and how to obtain them. Policy makers require better measurement tools and continuous monitoring, not only of employment and skills, but also of other related data such as compensation, mobility and immigration. Firms seek clearer signals on the supply of skilled workers while working out new ways of communicating their changing requirements in a more efficient and timely way to the educational system.

\section{Other stakeholders}

Australia, Canada, Ireland, the Netherlands, Sweden, the United Kingdom, the United States have all set up task forces to examine skills issues and suggest urgent action. The mandate of these bodies is often much broader than the narrow question of IT skills (both professional and basic) and often includes recommendations for other related areas of policy-making such as education and employment policy. In order for these to be effective, programmes aiming at building IT skills will need to be well-integrated into the educational, employment and other social and economic policy frameworks (Netherlands Ministry of Economic Affairs / Ministry of Education, Culture and Science, 2000). 
Table 7. Assessing costs and benefits of human capital investment

\begin{tabular}{|c|c|c|c|c|c|c|}
\hline \multirow[b]{3}{*}{$\begin{array}{l}\text { Compulsory } \\
\text { education }\end{array}$} & \multicolumn{2}{|c|}{ Individuals } & \multicolumn{2}{|c|}{ Enterprises } & \multicolumn{2}{|c|}{ Government/society } \\
\hline & Costs & Benefits & Costs & Benefits & Costs & Benefits \\
\hline & $\begin{array}{l}\text { Tuition fees and } \\
\text { other } \\
\text { educational } \\
\text { costs }\end{array}$ & $\begin{array}{l}\text { Future productive and } \\
\text { social capabilities and } \\
\text { better quality of life }\end{array}$ & $\begin{array}{l}\text { Some direct } \\
\text { financial } \\
\text { contributions }\end{array}$ & $\begin{array}{l}\text { Improved skills, } \\
\text { cognitive and } \\
\text { behavioural } \\
\text { attributes of } \\
\text { workers }\end{array}$ & $\begin{array}{l}\text { Direct } \\
\text { outlays }\end{array}$ & $\begin{array}{l}\text { Higher skill } \\
\text { levels, social } \\
\text { cohesion, } \\
\text { growth and tax } \\
\text { returns }\end{array}$ \\
\hline $\begin{array}{l}\text { Post- } \\
\text { compulsory } \\
\text { and higher } \\
\text { education }\end{array}$ & $\begin{array}{l}\text { Tuition fees, } \\
\text { other } \\
\text { educational } \\
\text { costs and } \\
\text { foregone } \\
\text { earnings while } \\
\text { studying }\end{array}$ & $\begin{array}{l}\text { Skills/qualifications } \\
\text { leading to higher } \\
\text { earnings, } \\
\text { employability and } \\
\text { quality of life }\end{array}$ & $\begin{array}{l}\text { Direct } \\
\text { financial } \\
\text { contributions }\end{array}$ & $\begin{array}{l}\text { Improved skills, } \\
\text { cognitive and } \\
\text { behavioural } \\
\text { attributes of } \\
\text { workers }\end{array}$ & $\begin{array}{l}\text { Direct } \\
\text { outlays on } \\
\text { educational } \\
\text { institutions, } \\
\text { transfers to } \\
\text { students }\end{array}$ & $\begin{array}{l}\text { Higher skill } \\
\text { levels, social } \\
\text { cohesion, } \\
\text { economic } \\
\text { growth and tax } \\
\text { returns }\end{array}$ \\
\hline $\begin{array}{l}\text { Enterprise } \\
\text { training }\end{array}$ & $\begin{array}{l}\text { Zero to full cost } \\
\text { depending on } \\
\text { terms of contract }\end{array}$ & $\begin{array}{l}\text { Studies suggest } \\
\text { positive impact on } \\
\text { wages, job tenure and } \\
\text { productivity }\end{array}$ & $\begin{array}{l}\text { Direct } \\
\text { outlays, } \\
\text { wages paid } \\
\text { and some } \\
\text { training } \\
\text { levies }\end{array}$ & $\begin{array}{l}\text { Enterprise- } \\
\text { specific } \\
\text { knowledge with } \\
\text { improvements } \\
\text { in productivity }\end{array}$ & $\begin{array}{l}\text { Zero to full } \\
\text { subsidy }\end{array}$ & $\begin{array}{l}\text { Higher skill } \\
\text { levels, social } \\
\text { cohesion, } \\
\text { economic } \\
\text { growth and tax } \\
\text { returns }\end{array}$ \\
\hline $\begin{array}{l}\text { Informal } \\
\text { learning }\end{array}$ & $\begin{array}{l}\text { Opportunity time } \\
\text { costs and direct } \\
\text { financial costs }\end{array}$ & $\begin{array}{l}\text { Economic and non- } \\
\text { economic gains } \\
\text { depending on } \\
\text { qualifications earned }\end{array}$ & $\begin{array}{l}\text { Cost of lost } \\
\text { production } \\
\text { time due to } \\
\text { learning }\end{array}$ & $\begin{array}{l}\text { Enterprise- } \\
\text { specific } \\
\text { knowledge with } \\
\text { improvements } \\
\text { in productivity }\end{array}$ & No cost & $\begin{array}{l}\text { Economic and } \\
\text { social spin-offs }\end{array}$ \\
\hline
\end{tabular}

Source: OECD (1998).

\section{Governments}

A wide range of policy recommendations and actions which different countries consider relevant to addressing the challenge of building ICT skills for the future is presented in Annex Table $3{ }^{26}$ Reviews of skill requirements in various OECD countries all point towards the need for a strong co-ordinating role by governments in addressing the inter-related issues. Through the use of both direct and indirect measures, governments can play a leading role in setting priorities and leveraging the action of other stakeholders. Table 8 summarises some of the main issues and policy areas for governments.

\section{Educational institutions}

Higher education institutions are facing the challenge of having to respond quickly in a rapidly moving area. The two main concerns regarding IT students are: $i$ ) ensuring that graduates have acquired the right balance of theoretical and more applied skills; and ii) incorporating the teaching of business/management skills and "soft" skills into technical degrees. To address the first goal, educational institutions must ensure that students are exposed to real-life situations and problems. In many countries, the importance of apprenticeships (or "co-ops") and other programmes where students gain on-the-job experience has been growing through partnerships with business. New forms of industry/academia collaborations should also be encouraged to attract qualified teaching staff given the salary differentials which often discourage computer science graduates from following academic careers. In terms of revising IT curricula, educational institutions are responding to concerns voiced by industry groups that many IT-related occupations require a broad range of often non-technical skills. Many business schools have begun to introduce innovative e-Business programmes that combine technical and business skills. ${ }^{27}$ 
DSTI/DOC(2002)10

Table 8. ICT skills: issues and actions

\begin{tabular}{|c|c|c|c|c|}
\hline & $\begin{array}{l}\text { Skills formation } \\
\text { (which skills?) }\end{array}$ & $\begin{array}{l}\text { Skills acquisition/renewal } \\
\text { (when and where?) }\end{array}$ & Main issues & Areas for government action \\
\hline \begin{tabular}{|l} 
Professional \\
ICT skills
\end{tabular} & $\begin{array}{l}\text { Skills required to } \\
\text { develop, use or service } \\
\text { ICTs professionally }\end{array}$ & $\begin{array}{l}\text { Post-secondary education, } \\
\text { IT vendor certification }\end{array}$ & $\begin{array}{l}\text { - Balancing specialist ICT } \\
\text { skills with other more } \\
\text { generic skills } \\
\text { - High mobility } \\
\text { - Recognition of non- } \\
\text { formal qualifications }\end{array}$ & $\begin{array}{l}\text { - Improve attractiveness of ICT } \\
\text { careers } \\
\text { - Assist in providing labour } \\
\text { market information } \\
\text { - Examine options for using } \\
\text { foreign labour }\end{array}$ \\
\hline $\begin{array}{l}\text { Applied ICT } \\
\text { skills }\end{array}$ & $\begin{array}{l}\text { Ability to use ICTs in } \\
\text { non-ICT jobs }\end{array}$ & $\begin{array}{l}\text { Post-compulsory education, } \\
\text { workplace training }\end{array}$ & $\begin{array}{l}\text { - Importance of integrating } \\
\text { ICT into a } \\
\text { sector/profession }\end{array}$ & $\begin{array}{l}\text { - Help identify emerging ICT skill } \\
\text { requirements for non-ICT jobs } \\
\text { - Provide incentives for firms to } \\
\text { train workers }\end{array}$ \\
\hline $\begin{array}{l}\begin{array}{l}\text { Basic ICT } \\
\text { skills }\end{array} \\
\end{array}$ & $\begin{array}{l}\text { Strong life-long learning } \\
\text { skills: fluency to use ICT } \\
\text { for learning, working, } \\
\text { recreation }\end{array}$ & $\begin{array}{l}\text { Learning context: schools } \\
\text { (children), training (adults) } \\
\text { [at work, formal courses, } \\
\text { informal exposure] }\end{array}$ & $\begin{array}{l}\text { - Developing common } \\
\text { standards } \\
\text { - Building core ICT } \\
\text { competencies in curricula } \\
\text { - Enhancing teacher skills }\end{array}$ & $\begin{array}{l}\text { - Promote ICT skills as important } \\
\text { "generic" skills for life-long } \\
\text { learning } \\
\text { - Facilitate roll-out of ICTs in } \\
\text { schools } \\
\text { - Promote ICT skills among } \\
\text { teachers }\end{array}$ \\
\hline
\end{tabular}

It is also important that existing educational institutions recognise the growing role of other actors such as private training firms and vendors, and engage in new partnerships to collaborate on issues of common concern such as developing and reviewing certification programmes.

\section{Individuals}

Clearly, individuals themselves have strong incentives to upgrade their skills although they often lack the information on how to do so. Students can benefit from better information on labour market prospects and clearer information on educational pathways to IT careers. Apprenticeship and other learning-at-work programmes contribute to raising the awareness of student to industry concerns, work methods and challenges. For workers, various reports stress the importance of self-training and the need for better information on the possibilities of retraining into IT jobs.

\section{Horizontal approaches and partnerships}

All the reports reviewed agree on the need for horizontal approaches involving all the stakeholders and coordinated action. The following section presents some promising examples.

In Australia, the government and the private sector are in the process of setting up an IT\&T Skills Exchange. The Exchange will be a privately incorporated body driven by industry needs, focused on providing just-in-time training, and complementing the public education and training infrastructure. The projects undertaken by the Exchange will involve three areas:

- A survey of industry demand for IT\&T skills, administered to around 3000 businesses Australia-wide.

- A survey of the current enrolment and completion rates of public and private education suppliers to determine the supply of IT\&T skills in Australia. 
- A systematic analysis of the survey outcomes to determine the economic implications of any shortfalls.

One of the main components of the IT Skills Hub is the IT Skills Hub portal, an electronic marketplace conceived to address the need for a larger IT skills pool in Australia. It provides information and resources on education, training, development and services for everyone involved in the sector - from users to suppliers, students to educators and employers to employees. The portal is a meeting space that links individuals with agencies with IT skills, opportunities and solutions and has three main roles:

- Intelligence gathering and dissemination;

- Facilitating education and training programs in new skill areas; and

- Creating awareness of IT careers.

In addition, regional authorities such as the State Governments of Victoria, New South Wales, and Queensland have been very active in recognising the importance of building a strong ICT skills base to strengthen both traditional and emerging industries (see for example Multimedia Victoria, 2000). The APEC Telecommunications and Information Working Group announced an initiative to address ecommerce skills gaps in the region and define standards. Australia will be leading this activity which also includes China, the Philippines and Indonesia (NOIE, 2001).

A study of skill requirements in the Canadian ICT sector (Denton and Pereboom, 1999) highlights the success of the "O-Vitesse" programme which provides university-level training to engineers, mathematicians and other qualified professionals in fields relevant to software development. The programme, which runs as a partnership between government, industry and educational institutions, was originally created by the National Research Council Canada and is now being privatised. A report prepared by the Canadian Expert Panel on Skills for the Advisory Council on Science \& Technology calls for new decision-making structures such as an executive agency which could be federally-funded and private sector-led, working on national, regional and local levels to integrate skills and enterprise development strategies (ACST, 2000).

In the United States, a report by the $21^{\text {st }}$ Century Workforce Commission presents numerous examples of programmes aimed at improving the connections between schools and workplaces. The Commission calls for Technology Opportunity Partnerships (TOPs) which should involve all stakeholders and address a variety of issues ranging from raising student achievement to identifying clear pathways for youth and adults seeking to enter IT careers $\left(21^{\text {st }}\right.$ Century Workforce Commission, 2000).

The Swedish Government has been collaborating with industry through a national IT training programme (SwIT). Government Bill 1997/98:1 allocated some SEK 1.3 billion to cover the costs of training courses, administration, evaluation and assessment, as well as unemployment training grants. This programme ran from 1998 to March 2000 and provided training for 11700 persons, mainly unemployed, focusing on three target groups: women, immigrants and occupationally disabled people. The average training period was 25 weeks. An initial evaluation of the programme indicated that $62 \%$ of those who participated in the programme were subsequently employed and $2 \%$ were pursuing higher education degrees. The results also indicated that SMEs found the programme to be very useful, valuing the close contact between the training organisation and local business communities. 


\section{IT skills for all?}

There is a growing recognition that the digital revolution has brought about the need for digital literacy, or widespread basic IT skills. In order to avoid digital exclusion, countries must ensure that IT skills are integrated into the concept of lifelong learning. All stakeholders agree on the need for an early introduction of students to computers and other new technologies (OECD, 2000b). Investments in technologies (hardware and software) must be accompanied by an adequate supply of qualified instructors able to teach these new skills, as well as innovative curricula which take into account the possibilities (and limitations) of the new technologies. Other possible actions include enhancing the opportunities for computer science graduates wanting to be teachers, strengthening the teaching of mathematics and other sciences and encouraging post-secondary students to take basic IT courses regardless of their main field of study. ${ }^{28} \mathrm{~A}$ wide range of OECD work has already addressed these issues and a detailed analysis falls outside the scope of this study.

Outside of the academic realm, a variety of different approaches to enhancing access to ICTs are emerging (c.f. the current debate on narrowing different "Digital Divides"). Some firms have chosen direct measures to enhance access of their workers to IT: low-cost PC programmes including Internet access have been recently launched by various large US firms (see Table 9). It is unclear whether firms in some European countries will be able to implement similar programmes given current taxation restrictions and the lack of widespread unmetered Internet access (OECD, 2001g).

Table 9. Examples of "PCs/Internet for employees" programmes in various firms

\begin{tabular}{|c|c|c|c|}
\hline Firm & Number of employees & Offer & Cost \\
\hline Ford & 360000 employees & $\begin{array}{l}\text { Computer, colour printer, } \\
\text { Internet access }\end{array}$ & 5 USD / month (3 years) \\
\hline Delta & 72000 employees & $\begin{array}{l}\text { Computer, printer, Internet } \\
\text { access }\end{array}$ & $\begin{array}{l}12 \text { USD / month (36 } \\
\text { months) }\end{array}$ \\
\hline $\begin{array}{l}\text { American Airlines } \\
\text { Intel }\end{array}$ & $\begin{array}{l}100000 \text { + employees } \\
70000 \text { employees }\end{array}$ & $\begin{array}{l}\text { PC, printer, Internet access } \\
\text { Pentium III package (incl. } \\
\text { Internet access) }\end{array}$ & 12 USD / month (3 years) \\
\hline $\begin{array}{l}\text { General Motors / } \\
\text { Daimler-Chrysler }\end{array}$ & 300000 employees & $\begin{array}{l}\text { Internet access (through } \\
\text { AOL) }\end{array}$ & $\begin{array}{l}3 \text { USD / month for standard } \\
\text { access; } 5 \text { USD / month for } \\
\text { AOL-TV (interactive TV) }\end{array}$ \\
\hline
\end{tabular}

Source: OECD based on various published sources.

Labour unions have also been active. In 1997, the Swedish Trade Union Confederation (LO) launched its home PC package programme for workers in order to help them master the IT skills needed in their work. The offer consists of a PC, a printer, Internet access and basic software, on a 36-month lease contract. Currently, more than 56000 families (or more than one in every 40 affiliated) have signed on this programme (http://www.lo.se). In the United States, the AFL-CIO is developing a range of initiatives such as offering low-price union-built PCs for its members while the site Workingfamilies.com offers low-cost Internet access.

\section{Summary and conclusions}

The preceding analysis of the IT workforce highlights the need to differentiate issues relating to the IT workforce (those with professional IT skills) from those relating to more applied IT skills across the economy and basic IT skills. With respect to claims of IT worker shortages, the evidence is not conclusive, but a gap does appear to exist between the skills sought by employers and those found in the workforce, mainly because of rapidly changing skill requirements. Both short- and long-term strategies can be pursued 
to address these new skill requirements, and most studies of OECD countries point to the need for similar measures that emphasise the need for better data and for government-industry partnerships. Policy makers and industry agree that all stakeholders have a role in implementing short-term solutions and in facilitating mechanisms for devising longer-term strategies.

\section{The IT workforce}

In order to ensure that the IT workforce is equipped with appropriate skills sets, various measures on the supply and demand sides can be used:

- On the supply side: providing more information to students, developing stronger IT skills in secondary schools, assisting in teacher training, making IT careers more attractive (in particular to under-represented groups such as women), ensuring better integration of educational programmes with "real world" problems, helping workers maintain up-to-date skills.

- On the demand and user side: better use by employers of the existing workforce (in terms both of recruitment and retention), more information on skill needs and opportunities (including pathways to IT jobs), adequate training programmes for various categories of workers (including unemployed and older workers) and government taking a lead role as model users.

Messages are more mixed in terms of immigration policy. Most countries seem to favour expanding the short-term supply of IT workers through the use of foreign labour, but some observers point to the risks of such solutions. Even temporary increases in supply (such as short-term immigration) can put downward pressure on wages, which in the medium-term might discourage more students from pursuing careers in this field and send conflicting signals to current IT workers and firms. ${ }^{29}$

\section{Basic IT skills}

There are strong reasons to believe that as IT continues to diffuse throughout the economy, basic IT skills are becoming a new category of "general" competency, like numeracy or literacy skills. ${ }^{30}$ IT skills not only increase the earnings potential of information workers, they are becoming necessary for a broad range of activities. Therefore, in addition to creating a larger and more skilled IT workforce, the focus should also be on building IT skills for all. Many countries have already formulated the explicit goal of achieving in the near future IT literacy for all students completing secondary education. To be effective, however, these programmes must be well integrated into broader policy frameworks such as those aimed at strengthening educational systems, promoting lifelong learning and facilitating workforce upskilling. 
DSTI/DOC(2002)10

\section{NOTES}

1. In this report, the terms IT and ICT are used interchangeably. Although the discussion most often refers to the "IT workforce" and IT workers, the data usually include telecommunication jobs to the extent that they relate to the IT infrastructure.

2. Even within ICT jobs, a distinction must be made between: routine technical work (sales, support, basic Web development), which is often tied to vendor products, subject to rapid obsolescence and the need for frequent training; the implementation of business applications (ICT business analysts); and "high-level" ICT roles (programmers, systems engineers/analysts).

3. The recent debate on the supply and demand of IT skills (and possible "gaps") must be examined in the context of earlier (and more general) concerns about "skill shortages" (Massé et al., 1998) and the effects of skill-biased technological change on employment and wages (OECD, 1996; Katz, 1999; Acemoglu, 2000).

Responses were received from 532 firms in a sample of 1493.

This includes the following IT occupations: computer programmers, computer engineers, computer systems analysts, database administrators, computer support specialists and all other computer scientists.

This figure is an overestimate of the actual number of ICT workers since it includes all employment in ICT-producing industries, as well as ICT jobs in other sectors.

For Europe, computer workers include ISCO-88 categories 213 and 312; for the United States, CPS categories 64, 65, 229, 308 and 309.

The ITAA study calculates the "skills gap" as follows: current demand (vacancies) times percentage of applicants that employers deem qualified to fill a specific job.

Vacancy rates are a useful but imperfect indicator of tightness in the labour market. Vacancies are to be expected in high-growth industries and occupations and can also mask inadequate recruitment practices (US DOC, 1999). In addition, various firms may advertise openings for a same (IT services) contract which they all expect to win, resulting in multiple counting of individual jobs.

It is estimated that in March 2001, almost $10 \%$ of layoffs in the United States took place in Internet-related firms (Industry Standard, 2001; BLS, 2001).

11. In the United Kingdom, for example, a survey on skills shortages revealed that the hardest to fill vacancies were for jobs in crafts (mechanic, carpenter, plumber, electrician) and sales/marketing, ahead of IT staff (Wilson, 2000).

12. Internal and external strategies are sometimes also referred to as functional and numerical, respectively (OECD, 1996).

The institutions covered in the survey usually award about one-third of all bachelor's degrees in these fields in the United States.

This does not provide an estimate on the number of persons with credentials since individuals often possess more than one. It is estimated that there are more than 37000 Microsoft Certified individuals in the United Kingdom and Ireland (DfEE, 2000a). 
15. Countries such as the Netherlands have recognised the need to facilitate certification mechanisms, including recognition of non-formal learning (Duvekot, 2000).

16. To address the lack of reliable data on the use of offshore workers and the international relocation of employment, the UK Institute of Employment Studies (IES) is co-ordinating the EU-funded EMERGENCE project (http://www.emergence.nu) which attempts to gather statistical evidence on international outsourcing activities.

17. The H1 visa programme was created in the 1960s to attract skilled non-immigrant workers to the United States. Following the Immigration Nursing Relief Act of 1989, H-1A visas were granted to registered nurses. Since 1995, this programme has been discontinued and all H1 visas are now H-1B (speciality worker). Numerical caps to the H-1B programme were first set by the US Congress in the early 1990s.

For more on the Indian software industry and its links to the United States see OECD, 2000a, Chapter 6. Immigration policies of host countries have a strong impact on education policy in home countries of IT workers such as India. Given the strong (and growing) demand for Indian IT professionals, the Indian government recently announced a decision to double the capacity of engineering colleges and to set up a task force on human resources development in [http://www.wired.com/news/business/0,1367,39902,00.html]

19. See OECD (2001f) Annex 5.D. for more detailed country-specific criteria and conditions for admission and DIMA (2001) for a comparison of policies relating to ICT skills for temporary business entry and students in various OECD and non-member countries.

Data on Green Cards were kindly provided to the OECD by the German Ministry of Employment.

As part of the recently disclosed New Zealand E-commerce Strategy, see http://www.ecommercesummit.govt.nz/minister/index.html

In several non-English-speaking countries, foreign language skills were often cited as an important asset for IT workers given the predominance of English as a technical language.

Autor (2000) argues that temporary help firms have an incentive to provide free general skills training given that their main role (and business) is to gather and sell information about worker "quality" to employers (screening).

The American Society for Training and Development (ASTD) estimates that between $11 \%$ and $13 \%$ of training expenditures in the US are currently allocated to IT training, including training for both IT employees, and for other categories of workers $\left(21^{\text {st }}\right.$ Century Workforce Commission, 2000). Statistics Finland estimated that in Finland in 1997, within all occupations at least one-third of employees had received employer-arranged computer training in the previous two years (Statistics Finland, 1999).

25. An oft-cited example is Nortel Networks' co-op programme in Canada and the United States, aimed at both high school and university students.

26. Button et al. (2000) provides a short overview of IT policies in various OECD and non-member economies relating to workforce and skill development.

27. See for example http://www.dmoz.org/Business/E-Commerce/Education/Degree_Programs/ for a list of ECommerce degree programmes offered at various institutions across OECD countries. Oglivie (2000) presents an overview of research and course offering related to e-commerce in Canadian universities.

By late 2001, the European/International Computer Driving Licence (ECDL/ICDL) programme had already exceeded the mark of 1.5 million persons certified with basic IT skills. At that time, there were over 10000 test centres worldwide issuing such certification (http://www.ecdl.com). 
While some observers point to the risk for developing countries of losing valuable human resources ("brain drain"), in India and other Asian countries, a new view is that scientists and engineers working overseas may represent a "brain bank" that can be drawn upon to encourage innovative development at home $(\mathrm{OECD}, 2000 c)$.

At their April 2001 meeting, OECD Education Ministers acknowledged the importance of developing ICT skills as a general competence, within the theme of fostering "Competencies for the Knowledge Society" (OECD, 2001d). 


\section{APPENDIX 1: NWCET INFORMATION TECHNOLOGY SKILL STANDARDS}

The Northwest Center for Emerging Technology (NWCET) (State of Washington, United States) has developed a list of IT skills standards based on eight career clusters. The standards enumerate technical skills, employability skills and foundation knowledge requirements for each cluster. The following table presents examples for the "digital media" and "network design and administration" clusters:

\begin{tabular}{|c|c|c|c|c|c|c|}
\hline $\begin{array}{l}\text { Career } \\
\text { cluster }\end{array}$ & $\begin{array}{l}\text { Representative } \\
\text { job titles }\end{array}$ & $\begin{array}{l}\text { Sample } \\
\text { critical work } \\
\text { function }\end{array}$ & $\begin{array}{l}\text { Sample key } \\
\text { activity }\end{array}$ & $\begin{array}{l}\text { Sample } \\
\text { performance } \\
\text { indicator }\end{array}$ & $\begin{array}{l}\text { Sample } \\
\text { technical } \\
\text { knowledge }\end{array}$ & $\begin{array}{l}\text { Sample } \\
\text { employability } \\
\text { skills }\end{array}$ \\
\hline Digital media & $\begin{array}{l}\text { Animator, 2D/3D } \\
\text { artist, media } \\
\text { specialist }\end{array}$ & $\begin{array}{l}\text { Produce visual } \\
\text { and functional } \\
\text { design }\end{array}$ & $\begin{array}{l}\text { Determine media } \\
\text { types and } \\
\text { delivery platform }\end{array}$ & $\begin{array}{l}\text { Chosen media } \\
\text { elements and } \\
\text { delivery platform } \\
\text { support project } \\
\text { goals }\end{array}$ & $\begin{array}{l}\text { Knowledge of } \\
\text { media types } \\
\text { and capabilities }\end{array}$ & $\begin{array}{l}\text { Ability to } \\
\text { present } \\
\text { technical } \\
\text { information }\end{array}$ \\
\hline $\begin{array}{l}\text { Network } \\
\text { design and } \\
\text { administration }\end{array}$ & $\begin{array}{l}\text { Network } \\
\text { technician, } \\
\text { network } \\
\text { engineer }\end{array}$ & $\begin{array}{l}\text { Perform } \\
\text { monitoring and } \\
\text { management }\end{array}$ & $\begin{array}{l}\text { Monitor and } \\
\text { report component } \\
\text { security and } \\
\text { connectivity } \\
\text { problems }\end{array}$ & $\begin{array}{l}\text { System is closely } \\
\text { monitored and } \\
\text { outages are } \\
\text { reported in a } \\
\text { timely manner }\end{array}$ & $\begin{array}{l}\text { Knowledge of } \\
\text { network } \\
\text { architecture, } \\
\text { topology, } \\
\text { hardware and } \\
\text { software }\end{array}$ & $\begin{array}{l}\text { Ability to } \\
\text { interpret and } \\
\text { evaluate data }\end{array}$ \\
\hline
\end{tabular}

Source: NWCET in ITAA (2000).

The following table presents the job titles for each of the eight career clusters:

\begin{tabular}{ll}
\hline Database administration and development & Designer \\
Data administrator & Media specialist \\
Data analyst & Media/instructional designer \\
Data architect & Multimedia author \\
Data management associate & Multimedia authoring specialist \\
Data modeler & Multimedia developer \\
Data modelling specialist & Multimedia specialist \\
Database administration associate & Producer \\
Database administrator & Production assistant \\
Database analyst & Programmer \\
Database developer & Streaming media specialist \\
Database manager & Virtual reality specialist \\
Database modeler & Web designer \\
Database security expert & Web producer \\
Decision Support Services (DSS) & Web specialist \\
Knowledge architect & Enterprise systems analysis and integration \\
Senior database administrator & Application integrator \\
Systems analyst & Business continuity analyst \\
Tester & Cross-enterprise integrator \\
Digital media & Data systems designer \\
2D/3D artist & Data systems manager \\
Animator & Data warehouse designer \\
Audio/video engineer & E-business specialist \\
\hline
\end{tabular}


DSTI/DOC(2002)10

\section{APPENDIX 1: NWCET SKILL STANDARDS (cont'd)}

\begin{tabular}{|c|c|}
\hline Electronic transactions implementer & Software QA specialist \\
\hline Information systems architect & Software tester \\
\hline Information systems planner & Systems analyst \\
\hline Systems analyst & Systems administrator \\
\hline Systems integrator & Test engineer \\
\hline Network design and administration & Tester \\
\hline Communications analyst & Technical support \\
\hline Data communications analyst & Analyst \\
\hline Information systems operator & Call centre support representative \\
\hline Information technology engineer & Content manager \\
\hline Network administrator & Customer liaison \\
\hline Network analyst & Customer service representative \\
\hline Network architect & Customer support professional \\
\hline Network engineer & Help desk specialist \\
\hline Network manager & Help desk technician \\
\hline Network operations analyst & Senior systems analyst \\
\hline Network security analyst & Systems analyst \\
\hline Network specialist & Technical account manager \\
\hline Network technician & Technical support engineer \\
\hline Network transport administrator & Technical support representative \\
\hline PC support specialist & Testing engineer \\
\hline PC network engineer & Technical writing \\
\hline Systems administrator & Desktop publisher \\
\hline Systems engineer & Document specialist \\
\hline Technical support specialist & Editor \\
\hline User support specialist & Electronic publications specialist \\
\hline Programming/software engineering & Electronic publisher \\
\hline Applications analyst & Instructional designer \\
\hline Applications engineer & Online publisher \\
\hline Business analyst & Technical communicator \\
\hline Computer engineer & Technical editor \\
\hline Data modeler & Technical publications manager \\
\hline Operating system designer/engineer & Technical writer \\
\hline Operating system programmer/analyst & Web development and administration \\
\hline Programme manager & Web administrator \\
\hline Programmer/analyst & Web architect \\
\hline Project lead & Web designer \\
\hline Software applications specialist & Web page developer \\
\hline Software architect & Web site developer \\
\hline Software design engineer & Web specialist \\
\hline Software design engineer and tester & Webmaster \\
\hline Software development engineer & \\
\hline
\end{tabular}


DSTI/DOC(2002)10

ANNEX TABLE 1: H-1 VISAS GRANTED IN THE UNITED STATES BY COUNTRY OF ORIGIN, 1989-99

\begin{tabular}{|c|c|c|c|c|c|c|c|c|c|c|c|}
\hline & 1989 & 1990 & 1991 & 1992 & 1993 & 1994 & 1995 & 1996 & 1997 & 1998 & 1999 \\
\hline India & 2144 & 2697 & 4102 & 5552 & 7606 & 11301 & 15528 & 19203 & 31686 & 40247 & 55047 \\
\hline United Kingdom & 6663 & 7174 & 8794 & 6726 & 3993 & 4230 & 4771 & 5601 & 6928 & 6343 & 6665 \\
\hline China & 837 & 610 & 1145 & 894 & 1031 & 1256 & 1887 & 2330 & 3214 & 3883 & 5779 \\
\hline Japan & 3678 & 3791 & 5167 & 2767 & 2152 & 2217 & 2070 & 2411 & 2929 & 2878 & 3339 \\
\hline Philippines & 6055 & 7302 & 7221 & 7550 & 7596 & 8753 & 10026 & 4601 & 2685 & 2758 & 3065 \\
\hline France & 2318 & 2293 & 2413 & 1686 & 870 & 1003 & 1216 & 1463 & 1894 & 2110 & 2633 \\
\hline Germany & 1798 & 1637 & 1888 & 1501 & 1012 & 1092 & 1484 & 1518 & 2088 & 2242 & 2451 \\
\hline Mexico & 2951 & 3727 & 3227 & 2488 & 1307 & 1147 & 1451 & 1909 & 2785 & 2320 & 2419 \\
\hline Australia & 872 & 827 & 1102 & 990 & 863 & 1050 & 1042 & 1123 & 1438 & 1666 & 1651 \\
\hline Russia & 2256 & 3709 & 3942 & 1651 & 1892 & 1245 & 1196 & 1255 & 1357 & 1395 & 1619 \\
\hline Other & 19248 & 24906 & 20324 & 19862 & 13884 & 15990 & 18422 & 18658 & 23604 & 25536 & 32027 \\
\hline Total & 48820 & 58673 & 59325 & 51667 & 42206 & 49284 & 59093 & 60072 & 80608 & 91378 & 116695 \\
\hline
\end{tabular}


ANNEX TABLE 2: EXAMPLES OF POLICY ACTIONS AND RECOMMENDATIONS FOR BUILDING ICT SKILLS

\begin{tabular}{|c|c|c|c|c|c|c|c|}
\hline & & & & \multicolumn{3}{|c|}{ Skills } & Other policies \\
\hline Country & Body & Report/Programme & Target & IT professional & Basic IT & General & Immigration \\
\hline $\begin{array}{l}\text { Australia } \\
\end{array}$ & Government & $\begin{array}{l}\text { Backing Australia's } \\
\text { Ability }\end{array}$ & $\begin{array}{l}\text { Educational } \\
\text { Institutions }\end{array}$ & $\begin{array}{l}2000 \text { additional university places } \\
\text { in IT, maths and science each } \\
\text { year for } 5 \text { years }\end{array}$ & & & \\
\hline & & & Industry & & & & $\begin{array}{l}\text { Streamlining of } \\
\text { migration } \\
\text { arrangements } \\
\text { for ICT } \\
\text { professionals } \\
\end{array}$ \\
\hline & & & $\begin{array}{l}\text { Educational } \\
\text { Institutions }\end{array}$ & & $\begin{array}{l}\text { The Learning Federation - } \\
\text { an initiative to deliver Online } \\
\text { Curriculum Content for } \\
\text { Australian Schools }\end{array}$ & & \\
\hline & Government & 2002 Budget statement & & & \begin{tabular}{|l|} 
IT Skills for Older Workers \\
program. Basic computer \\
training for 46000 people \\
over 4 years, particularly \\
those who are welfare \\
dependant and over \\
45 years old
\end{tabular} & & \\
\hline
\end{tabular}


ANNEX TABLE 2: EXAMPLES OF POLICY ACTIONS AND RECOMMENDATIONS FOR BUILDING ICT SKILLS (cont'd)

\begin{tabular}{|c|c|c|c|c|c|c|c|}
\hline & & & & \multicolumn{3}{|c|}{ Skills } & Other policies \\
\hline Country & Body & Report/Programme & Target & IT professional & Basic IT & General & Immigration \\
\hline Australia & & & Industry & 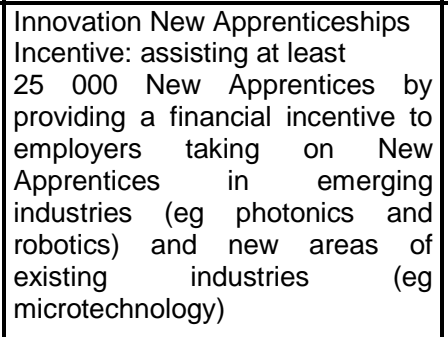 & & & \\
\hline & $\begin{array}{l}\text { Government } \\
\text { and Industry }\end{array}$ & IT Skills Hub & $\begin{array}{l}\text { All } \\
\text { stakeholders }\end{array}$ & $\begin{array}{l}\text { Linkages between industry and } \\
\text { education providers. Broking } \\
\text { courses in areas of indentified } \\
\text { skills needs. Creating awareness } \\
\text { of ICT careers with secondary } \\
\text { students }\end{array}$ & $\begin{array}{l}\text { Development of } \\
\text { e-business courses tailored } \\
\text { to specific industry sectors } \\
\text { (eg Building industry SMEs) }\end{array}$ & & \\
\hline Canada & $\begin{array}{l}\text { Expert Panel on } \\
\text { Skills }\end{array}$ & $\begin{array}{l}\text { Stepping Up: Skills and } \\
\text { Opportunities in the } \\
\text { Knowledge Economy }\end{array}$ & Government & & & $\begin{array}{l}\text { Development of } \\
\text { standard skill } \\
\text { definitions and } \\
\text { measurement tools }\end{array}$ & $\begin{array}{l}\text { Expand model } \\
\text { of temporary } \\
\text { workers from } \\
\text { software to other } \\
\text { sectors }\end{array}$ \\
\hline & & & $\begin{array}{l}\text { Educational } \\
\text { institutions }\end{array}$ & $\begin{array}{l}\text { Review apprenticeship } \\
\text { programmes with industry } \\
\text { partners }\end{array}$ & $\begin{array}{l}\text { Ensure current teachers } \\
\text { have up-to-date skills }\end{array}$ & \begin{tabular}{|l} 
Measure the \\
acquisition of \\
essential skills
\end{tabular} & $\begin{array}{l}\text { Facilitate hiring } \\
\text { of foreign } \\
\text { nationals to } \\
\text { faculty positions }\end{array}$ \\
\hline
\end{tabular}


ANNEX TABLE 2: EXAMPLES OF POLICY ACTIONS AND RECOMMENDATIONS FOR BUILDING ICT SKILLS (cont'd)

\begin{tabular}{|c|c|c|c|c|c|c|c|}
\hline & & & & \multicolumn{3}{|c|}{ Skills } & Other policies \\
\hline Country & Body & Report/Programme & Target & IT professional & Basic IT & General & Immigration \\
\hline Canada & & & Industry & & & & $\begin{array}{l}\text { Involve industry } \\
\text { sector councils } \\
\text { in } \\
\text { implementation } \\
\text { of new approach } \\
\text { to selection and } \\
\text { recruitment of } \\
\text { foreign workers }\end{array}$ \\
\hline $\begin{array}{l}\text { European } \\
\text { Union }\end{array}$ & \begin{tabular}{|l|} 
European \\
Commission
\end{tabular} & $\begin{array}{l}\text { eEurope 2000: An } \\
\text { Information Society for } \\
\text { All }\end{array}$ & Government & & $\begin{array}{l}\text { European diploma for basic } \\
\text { IT skills }\end{array}$ & & \\
\hline & & & \begin{tabular}{l|} 
Educational \\
institutions
\end{tabular} & & $\begin{array}{l}\text { Connecting schools, } \\
\text { incentives for teachers to } \\
\text { use IT }\end{array}$ & $\begin{array}{l}\text { Adapt school curricula } \\
\text { to new ways of } \\
\text { learning using ICTs }\end{array}$ & \\
\hline & & & Industry & $\begin{array}{l}\text { Accelerate development of e- } \\
\text { commerce }\end{array}$ & Promote IT training & & \\
\hline Greece & Government & $\begin{array}{l}\text { Operational } \\
\text { Programme } \\
\text { Information Society }\end{array}$ & & $\begin{array}{l}\text { Close the "skills gap" combining } \\
\text { advanced ICT skills training and } \\
\text { "on-the-job" training for } 10,000 \\
\text { persons (2002-2002) }\end{array}$ & $\begin{array}{l}\text { Certification of qualifications } \\
\text { for } 40,000 \text { people in basic IT } \\
\text { skills (2001-2002), focusing } \\
\text { on unemployed }\end{array}$ & & \\
\hline Hungary & Government & $\begin{array}{l}\text { "Sulinet" (Schoolnet) } \\
\text { Programme }\end{array}$ & & & $\begin{array}{l}\text { Providing primary and } \\
\text { secondary schools with } \\
\text { Internet access and making } \\
\text { IT an important feature of } \\
\text { teacher training }\end{array}$ & & \\
\hline
\end{tabular}


ANNEX TABLE 2: EXAMPLES OF POLICY ACTIONS AND RECOMMENDATIONS FOR BUILDING ICT SKILLS (cont'd)

\begin{tabular}{|c|c|c|c|c|c|c|c|}
\hline & & & & \multicolumn{3}{|c|}{ Skills } & Other policies \\
\hline Country & Body & Report/Programme & Target & IT professional & Basic IT & General & Immigration \\
\hline Ireland & $\begin{array}{l}\text { Expert Group } \\
\text { on Future Skills } \\
\text { Needs }\end{array}$ & $\begin{array}{l}\text { Report on e-Business } \\
\text { Skills }\end{array}$ & Government & $\begin{array}{l}\text { Work with educational institutions } \\
\text { to develop e-Business } \\
\text { programmes }\end{array}$ & & & \\
\hline & & & $\begin{array}{l}\text { Educational } \\
\text { institutions }\end{array}$ & Promote e-Business degrees & $\begin{array}{l}\text { Update skills of business } \\
\text { school faculty }\end{array}$ & & \\
\hline & & & & & $\begin{array}{l}\text { Promote a second level ICT } \\
\text { skills common standard }\end{array}$ & & \\
\hline & & & Industry & & & & \\
\hline & $\begin{array}{l}\text { Expert Group } \\
\text { on Future Skills } \\
\text { Needs }\end{array}$ & Second Report & Government & $\begin{array}{l}\text { Monitor recommendations of First } \\
\text { Report (1998) }\end{array}$ & & \begin{tabular}{|l|} 
Use of ICTs to \\
promote job \\
opportunities in \\
Ireland to non- \\
residents \\
\end{tabular} & \\
\hline & & & $\begin{array}{l}\text { Educational } \\
\text { institutions }\end{array}$ & $\begin{array}{l}\text { Increase numbers on Accelerated } \\
\text { Technician Programmes in } \\
\text { computer science }\end{array}$ & Awareness campaigns & & \\
\hline & & & Industry & Support to train workers & & $\begin{array}{l}\text { More flexible working } \\
\text { arrangements and } \\
\text { non-pay incentives }\end{array}$ & \\
\hline Norway & $\begin{array}{l}\text { Ministry of } \\
\text { Education, } \\
\text { Research and } \\
\text { Church Affairs }\end{array}$ & $\begin{array}{l}\text { ICT in Norwegian } \\
\text { Education: Plan for } \\
\text { 2000-2003 }\end{array}$ & $\begin{array}{l}\text { Government } \\
\text { and } \\
\text { educational } \\
\text { institutions }\end{array}$ & $\begin{array}{l}\text { Report has been commissioned } \\
\text { on the need for ICT competencies } \\
\text { in the years to come }\end{array}$ & $\begin{array}{l}\text { Funding of the "Seniornett" } \\
\text { programme to provide older } \\
\text { people with opportunities to } \\
\text { develop ICT skills }\end{array}$ & & \\
\hline
\end{tabular}


ANNEX TABLE 2: EXAMPLES OF POLICY ACTIONS AND RECOMMENDATIONS FOR BUILDING ICT SKILLS (cont'd)

\begin{tabular}{|c|c|c|c|c|c|c|c|}
\hline & & & & \multicolumn{3}{|c|}{ Skills } & Other policies \\
\hline Country & Body & Report/Programme & Target & IT professional & Basic IT & General & Immigration \\
\hline Norway & Government & & $\begin{array}{l}\text { All } \\
\text { stakeholders }\end{array}$ & & $\begin{array}{l}\text { Within the "Competence } \\
\text { Reform" framework (for } \\
\text { Lifelong Learning), a project } \\
\text { will be established on "ICT } \\
\text { for Everybody" }\end{array}$ & & $\begin{array}{l}\text { Revise } \\
\text { regulations to } \\
\text { simplify the } \\
\text { recruitment of } \\
\text { skilled workers } \\
\text { from countries } \\
\text { outside the EEA } \\
\text { area. }\end{array}$ \\
\hline Spain & $\begin{array}{l}\text { Ministry of } \\
\text { Labour and } \\
\text { Social Affairs }\end{array}$ & & $\begin{array}{l}\text { Government } \\
\text { and industry } \\
\text { associations }\end{array}$ & $\begin{array}{l}\text { Training programmes for IT } \\
\text { workers }\end{array}$ & & & \\
\hline & $\begin{array}{l}\text { Ministry of } \\
\text { Science and } \\
\text { Technology }\end{array}$ & FORINTEL & & $\begin{array}{l}\text { Continuing education courses for } \\
\text { ICT sector workers }\end{array}$ & $\begin{array}{l}\text { Encourage acquisition of } \\
\text { basic IT skills by all citizens, } \\
\text { focusing on disadvantaged } \\
\text { groups (handicapped, } \\
\text { immigrants, long-term } \\
\text { unemployed) }\end{array}$ & & \\
\hline Sweden & Government & $\begin{array}{l}\text { Bill 1999/2000:86 (in } \\
\text { Ministry of Industry, } \\
\text { Employment \& } \\
\text { Communic., 2000) }\end{array}$ & Government & & $\begin{array}{l}\text { Analysis of women's use of } \\
\text { IT }\end{array}$ & & \\
\hline
\end{tabular}


ANNEX TABLE 2: EXAMPLES OF POLICY ACTIONS AND RECOMMENDATIONS FOR BUILDING ICT SKILLS (cont'd)

\begin{tabular}{|c|c|c|c|c|c|c|c|}
\hline & \multirow[b]{2}{*}{ Body } & \multirow[b]{2}{*}{ Report/Programme } & \multirow[b]{2}{*}{ Target } & \multicolumn{3}{|c|}{ Skills } & \multirow{2}{*}{$\begin{array}{c}\text { Other policies } \\
\text { Immigration }\end{array}$} \\
\hline Country & & & & \multicolumn{3}{|l|}{ IT professional } & \\
\hline Sweden & & & $\begin{array}{l}\text { Educational } \\
\text { institutions }\end{array}$ & $\begin{array}{l}\text { Royal Institute of Technology to } \\
\text { launch an "IT University", } \\
\text { development of a competence } \\
\text { centre for Internet technology }\end{array}$ & \begin{tabular}{|l} 
Continue special IT \\
Programme for schools \\
(ITiS)
\end{tabular} & & \\
\hline & & & Industry & & $\begin{array}{l}\text { IT competence } \\
\text { enhancement programme } \\
\text { for small firms }\end{array}$ & & \\
\hline $\begin{array}{l}\text { United } \\
\text { Kingdom }\end{array}$ & $\begin{array}{l}\text { National Skills } \\
\text { Task Force }\end{array}$ & Final Report & Government & Skill dialogues with industry & & $\begin{array}{l}\text { Information on labour } \\
\text { markets and skill } \\
\text { needs }\end{array}$ & $\begin{array}{l}\text { Examine } \\
\text { whether specific } \\
\text { ICT occupations } \\
\text { should be } \\
\text { included in } \\
\text { "shortage } \\
\text { occupation list" } \\
\end{array}$ \\
\hline & & & $\begin{array}{l}\text { Educational } \\
\text { institutions }\end{array}$ & $\begin{array}{l}\text { Collaboration with industry } \\
\text { (apprenticeships) }\end{array}$ & & $\begin{array}{l}\text { Improve foundation } \\
\text { learning system }\end{array}$ & \\
\hline & & & Industry & $\begin{array}{l}\text { NTOs should review occupational } \\
\text { framework }\end{array}$ & & & \\
\hline & & & & $\begin{array}{l}\text { Campaign to create a more } \\
\text { positive image of IT career } \\
\text { prospects }\end{array}$ & & & \\
\hline & & & & Small Firms Training Loans & & & \\
\hline & & & Individuals & Career Development Loans & & $\begin{array}{l}\text { Individual Learning } \\
\text { Accounts (ILAs) }\end{array}$ & \\
\hline
\end{tabular}


ANNEX TABLE 2: EXAMPLES OF POLICY ACTIONS AND RECOMMENDATIONS FOR BUILDING ICT SKILLS (cont'd)

\begin{tabular}{|l|l|l|l|l|l|l|}
\hline & & & & \multicolumn{1}{|c|}{ Skills } & \multicolumn{1}{|c|}{ Other policies } \\
\hline Country & \multicolumn{1}{|c|}{ Body } & Report/Programme & Target & \multicolumn{1}{|c|}{ IT professional } & \multicolumn{1}{|c|}{ Immigration } \\
\hline $\begin{array}{l}\text { United } \\
\text { States }\end{array}$ & $\begin{array}{l}\text { National } \\
\text { Research } \\
\text { Council }\end{array}$ & $\begin{array}{l}\text { Building a Workforce } \\
\text { for the Information } \\
\text { Economy }\end{array}$ & Government & $\begin{array}{l}\text { Collect better data on IT } \\
\text { workforce; enhance the } \\
\text { attractiveness of Government as } \\
\text { an IT employer }\end{array}$ & $\begin{array}{l}\text { Incentives for firms to } \\
\text { provide training (tax credits, } \\
\text { subsides loans, direct } \\
\text { grants) }\end{array}$ & $\begin{array}{l}\text { Increase portability } \\
\text { of H-1B visas, } \\
\text { streamline green- } \\
\text { card process }\end{array}$ \\
\hline & & & & $\begin{array}{l}\text { Educational } \\
\text { institutions }\end{array}$ & $\begin{array}{l}\text { Better align educational } \\
\text { programmes with industry needs }\end{array}$ & $\begin{array}{l}\text { Promote IT fluency in } \\
\text { primary and secondary } \\
\text { schools }\end{array}$ \\
\hline & & & $\begin{array}{l}\text { Improve secondary } \\
\text { mathematics } \\
\text { education }\end{array}$ & \\
\hline & & & Industry & Improve recruitment practices & Promote training \\
\hline & & & $\begin{array}{l}\text { Stronger links with educational } \\
\text { institutions }\end{array}$ & & \\
\hline & & & for all majors & \\
\hline & & & Individuals & Seek internships with IT firms & $\begin{array}{l}\text { Take advantage of training } \\
\text { opportunities offered by } \\
\text { employers and educational } \\
\text { instit. }\end{array}$ & \\
\hline
\end{tabular}


ANNEX TABLE 2: EXAMPLES OF POLICY ACTIONS AND RECOMMENDATIONS FOR BUILDING ICT SKILLS (cont'd)

\begin{tabular}{|c|c|c|c|c|c|c|c|}
\hline & & & & \multicolumn{3}{|c|}{ Skills } & Other policies \\
\hline \begin{tabular}{|l} 
Country \\
\end{tabular} & Body & Report/Programme & Target & IT professional & Basic IT & General & Immigration \\
\hline $\begin{array}{l}\text { United } \\
\text { States }\end{array}$ & $\begin{array}{l}21 \text { st Century } \\
\text { Workforce } \\
\text { Commission }\end{array}$ & \begin{tabular}{|l} 
A Nation of \\
Opportunity
\end{tabular} & Government & & $\begin{array}{l}\text { Implement IT skills training } \\
\text { tax credit for firms }\end{array}$ & & $\begin{array}{l}\text { Facilitate transition } \\
\text { of students } \\
\text { applying for H-1B } \\
\text { visas; raise } \\
\text { employer fees for } \\
\text { visa petitions } \\
\text { (which are then } \\
\text { used for education } \\
\text { and training } \\
\text { programmes) }\end{array}$ \\
\hline & & & \begin{tabular}{|l} 
Educational \\
institutions
\end{tabular} & $\begin{array}{l}\text { Making IT curriculum more } \\
\text { relevant to industry needs }\end{array}$ & \begin{tabular}{|l} 
Offer teachers work \\
experience opportunities \\
within IT firms
\end{tabular} & & \\
\hline & & & Industry & $\begin{array}{l}\text { Partnerships with teaching } \\
\text { institutions }\end{array}$ & & & \\
\hline
\end{tabular}


DSTI/DOC(2002)10

\section{REFERENCES}

$21^{\text {st }}$ Century Workforce Commission (2000), A Nation of Opportunity: Building America's $21^{\text {st }}$ Century Workforce. http://www.workforce21.org/finalreport.htm

Acemoglu, D. (2000), “Technical Change, Inequality and the Labor Market”, NBER Working Paper No. 7800, July. http://www.nber.org/papers/w7800

Adelman, C. (2000), "A Parallel Universe Expanded: Certification in the Information Technology Guild", revised version of article first appearing in Change, Vol. 32 No. 3, May-June: http://www.aahe.org/change/paralleluniverse.htm

Advisory Council on Science and Technology (Canada) (ACST) (2000), Stepping Up: Skills and Opportunities in the Knowledge Economy, Report of the Expert Panel on Skills. http://acstccst.gc.ca/acst/skills/home_e.html

Ahn S. and P. Hemmings (2000), "Policy Influences of Economic Growth in OECD Countries: An Evaluation of the Evidence", OECD Economics Department Working Papers No. 246, June. http://www.oecd.org/eco/eco

Alliance for Information Systems Skills (AISS) / IT National Training Organisaton (United Kingdom) (ITNTO) (1999), Skills 99, Report for the Department of Trade and Industry and the Department for Education and Employment (United Kingdom).

ASSINFORM/Netconsulting/ESDW-UNIMIB (2000), Rapporto 2000 sull'Occupazione nel settore dell'Informatica e delle Telecommunicazioni in Italia:

http://www.assinform.it/aree_sx/pubblicazioni/index_rapporto_occupazione2000a.htm

Association pour l'emploi des cadres (APEC) (2001), Panel Entreprises Apec: Emploi Cadre - Bilan 2000, Perspectives 2001. http://www.apec.asso.fr/

Association pour l'emploi des cadres (APEC) (2002), Panel Entreprises Apec: Emploi Cadre - Bilan 2001, Perspectives 2002. http://www.apec.asso.fr/

Autor, D. H. (2000), “Why Do Temporary Help Firms Provide Free General Skills Training?”, NBER Working Paper No. W7637, April. http://papers.nber.org/papers/W7637

Bresnahan, T. F., E. Brynjolfsson and L. M. Hitt (1999), "Information Technology and Recent Changes in Work Organization Increase the Demand for Skilled Labor", February. Stanford University.

Business 2.0 (2000), “Talent Crunch”, October 10.

Button K., K. Cox, R. Stough and S. Taylor (2000), "Comparative Analysis of International Policy and Practice for High-Technology Workforce Development", Mason Enterprise Center, School of Public Policy, George Mason University, May. http://www.workforce21.org/comparative_analysis.htm 
Canadian Policy Research Networks (CPRN) (2001), "Economic Migrants in a Global Labour Market: A Report on the Recruitment and Retention of Asian Computer Professionals by Canadian High-tech Firms", CPRN Discussion Paper No. W|13, July. http://www.cprn.org

Cappelli, P. (2000), "Is there A Shortage of Information Technology Workers?", Wharton School, University of Pennsylvania, report prepared for McKinsey and Co., June.

Computing Research Association (CRA) (2000), "1998-1999 Taulbee Survey”, Computing Research News, Vol. 12, No.2, March. http://www.cra.org/CRN/online.html

Computing Research Association (CRA) (2001), "1999-2000 Taulbee Survey", Computing Research News, Vol. 13, No.2, March. http://www.cra.org/CRN/online.html

Council of European Professional Informatics Societies (CEPIS) (2001), European Informatics Skills Structure. http://www.cepis.org/prof/eiss.htm

Denton, T. and B. Pereboom (1999), "Profile of the Information and Communications Technologies Sector", report prepared for the Expert Panel on Skills. http://acst-ccst.gc.ca/skills

Department of Employment and Workplace Relations (DEWR) (Australia) (2002), "ICT Vacancy Index". http://www.workplace.gov.au/

Department of Immigration and Cultural Affairs (DIMA) (Australia) (2001), "ICT in Focus: Immigration Initiatives for Australia's ICT Industry Innovation Action Plan", January.

http://www.dima.gov.au/ict/index.html

Department for Education and Employment (DfEE) (United Kingdom) (2000a), Skills for the Information Age, Final Report from the Information Technology, Communications and Electronic Skills Strategy Group, http://www.dfee.gov.uk/skillsforce/index.htm

Department for Education and Employment (DfEE) (United Kingdom) (2000b), Skills for All: Proposals for a National Skills Agenda, Final Report of the National Skills Task Force, June. http://www.dfee.gov.uk/skillsforce/index.htm

Ducatel, K. and J.-C. Burgelman (2000), "ICTs and Employment in Europe: Outlook to 2010", paper presented at the EURO-CPR 2000 Conference, Venice, March.

Duvekot, R. (2000), "Working and Learning Together: A Model for European Cooperation", Ministry of Economic Affairs of the Netherlands, paper presented for the Conference on "Identification, Assessment and Recognition of Non-Formal Learning: European Experiences and Solutions", Lillehammer, Norway, 15-16 May.

Ellis, R. and B. L. Lowell (1999a), "Core Occupations of the US Information Technology Workforce", Report 1 of the Information Technology Workforce Data Project, United Engineering Foundation, November. http://www.uefoundation.org/itworkfp.html

Ellis, R. and B. L. Lowell (1999b), "The Production of US Degrees in Information Technology Disciplines", Report 2 of the Information Technology Workforce Data Project, United Engineering Foundation, November. http://www.uefoundation.org/itworkfp.html 
Ellis, R. and B. L. Lowell (1999c), "Foreign Origin Persons in the US Information Technology Workforce", Report 3 of the Information Technology Workforce Data Project, United Engineering Foundation, November. http://www.uefoundation.org/itworkfp.html

Ellis, R. and B. L. Lowell (1999d), “Assessing the Demand for Information Technology Workers”, Report 4 of the Information Technology Workforce Data Project, United Engineering Foundation, November. http://www.uefoundation.org/itworkfp.html

Emergence (2001), "Where the Butterfly Alights: the Global Location of eWork", Press Release. http://www.emergence.nu/news/balights.html

European Information Technology Observatory (EITO) (2001), EITO 2001, Frankfurt am Main.

Forfás (2000a), Second Report of the Expert Group on Future Skills Needs: http://www.forfas.ie/publications/fskills_2.htm

Forfás (2000b), Report on e-Business Skills, Expert Group on Future Skills Needs: http://www.forfas.ie/publications/e-business_skills.htm

Gingras, Y. and R. Roy (1998), "Is there a Skills Gap in Canada?", Human Resources Development Canada, October.

Helliwell, J. F. (1999), "Checking the Brain Drain: Evidence and Implications", report prepared for the Expert Panel on Skills. http://acst-ccst.gc.ca/skills

Hendry, C. (1999), Skills Task Force Research Paper No. 10: New Technology Industries, September. http://www.dfee.gov.uk/skillsforce

Hoch, D. J., C. R. Roeding, G. Purkert and S. K. Lindner (2000), Secrets of Software Success: Management Insights from 100 Software Firms Around the World, Harvard Business School Press, Boston MA.

Industry Standard (2001), "Putting Layoffs in Perspective", 23 April.

Information Technology Association of America (ITAA) (2000), Bridging the Gap: Information Technology Skills For A New Millennium, April. http://www.itaa.org

Information Technology Association of America (ITAA) (2001), Where Can You Start? Building Better Information Technology Skills and Careers, Executive Summary, April.

Institute for Employment Studies (IES) (2002), An Assessment of Skill Needs in Information and Communication Technology, report prepared for the ICT Skills Dialogue, United Kingdom. http://www.skillsbase.dfee.gov.uk/Downloads/ICTreport.pdf

Institute for the Management of Information Systems (IMIS) (2001), What Skills Shortages? 2001 IT Skills Trend Report, Discussion draft for IMIS and Computer Weekly 500 Club, Management Summary, August. http://www.imis.org.uk/members/a_white/skills-shortage.pdf

International Labour Office (ILO) (2001), World Employment Report 2001: Life At Work in the Information Economy, Geneva. 
Ireland Information Society Commission (ISC) (2000a), IT Access for All, March. http://www.infosocomm.ie

Ireland Information Society Commission (ISC) (2000b), New Technology in Irish Business: Skills and Training (Business 3), May. http://ww.infosocomm.ie

IT National Training Organisation (United Kingdom) (ITNTO) (2000), Tracking the Skills for Prosperity, August. http://www.sfia.org.uk/What_SFIA_is/sfiaintro_1_1.pdf

Katz, L. F. (1999), “Technological Change, Computerization and the Wage Structure”, paper presented at the Conference on "Understanding the Digital Economy: Data, Tools and Research", Washington, DC, 25-26 May.

Klotz, U. (2000), "Facts on the IT Labour Market", IBITS, April: http://www.unionnetwork.org/uniibits.nsf

Lowell, B. L. (2000), "H1-B Temporary Workers: Estimating the Population”, Institute for the Study of International Migration, Georgetown University, April.

Makimoto, T. and D. Manners (1997), Digital Nomad, John Wiley \& Sons.

Massé, P., R. Roy and Y. Gingras (1998), "The Changing Skill Structure of Employment in Canada”, R99-7E, Human Resources Development Canada, November.

Matloff, N. (1998), "Debunking the Myth of a Desperate Software Labor Shortage", University of California at Davis, Testimony to the US House Judiciary Committee - Subcommittee on Immigration, 21 April (updated October 2000). http://heather.cs.ucdavis.edu/itaa.real.html

Ministère du Travail - DARES (2000), Premières Synthèses, No. 22.1, June. http://www.travail.gouv.fr

Ministry of Economic Affairs/Ministry of Education, Culture and Science (Netherlands) (2000), Competing with ICT Competencies: Know-how and Innovation for the Dutch Digital Delta, April.

Ministry of Industry, Employment and Communications (Sweden) (2000a), The Development of IT Skills, N 2000.076, December, http://www.naring.regeringen.se/pressinfo/infomaterial/pdf/n2000_076en.pdf

Ministry of Industry, Employment and Communications (Sweden) (2000b), "An Information Society for All”, Fact Sheet N.2000.018, March.

Multimedia Victoria (2000), Skills $x$ Knowledge $=$ Growth, State Government of Victoria (Australia), October.

National Center for Education Statistics (United States) (NCES) (2001), Digest of Education Statistics, NCES-2001-034. http://nces.ed.gov/pubs2001/digest/

National Office for the Information Economy (Australia) (NOIE) (2001), “APEC TEL Aims to Remedy ICT Skills Shortage in Asia-Pacific Region”, Press Release, 16 March.

OECD (1996), Technology, Productivity and Job Creation, Vol.2: Analytical Report, Paris. 
OECD (1998), Human Capital Investment: An International Comparison, Centre for Educational Research and Innovation, Paris.

OECD (1999), The Economic and Social Impacts of Electronic Commerce, Paris.

OECD (2000a), Information Technology Outlook 2000, Paris.

OECD (2000b), Learning to Bridge the Digital Divide, Centre for Educational Research and Innovation (CERI), US National Center on Adult Literacy (NCAL), Paris.

OECD (2000c), Proceedings of the "Joint German - OECD Conference on Benchmarking Industry-Science Relationships", held in Berlin 16-17 October 2000, Paris.

http://www.oecd.org/pdf/M00008000/M00008214.pdf

OECD (2001a), "Knowledge, Work Organisation and Economic Growth", Labour Market and Social Policy - Occasional Papers, No. 50, DEELSA/ELSA/WD(2001)3, Paris.

OECD (2001b), The New Economy: Beyond the Hype - The OECD Growth Project, Paris.

OECD (2001c), The Well-being of Nations: the Role of Human and Social Capital, Centre for Educational Research and Innovation (CERI), Paris.

OECD (2001d), Education Policy Analysis 2001, Paris.

OECD (2001e), Trends in International Migration - SOPEMI Annual Report 2000, Paris.

OECD (2001f), OECD Employment Outlook 2001, Paris.

OECD (2001g), Communications Outlook 2001, Paris.

Oglivie, K. (2000), Electronic Commerce in Canadian Universities, Report from the Talent Pool e-Team of The Canadian e-Business Opportunities Roundtable, November. http://e-com.ic.gc.ca/eteam/

Romer, P. (2000), "Should the Government Subsidize Supply or Demand in the Market for Scientists and Engineers?”, NBER Working Paper No. 7723, June. http://www.nber.org/papers/w7723

Roy R., H. Henson and C. Lavoie (1996), A Primer on Skill Shortages in Canada, R096-8E, Human Resources Development Canada.

Sangster, D. (1999), "Critical Skills in Five Canadian Industries: A Summary Report on Sectoral Interviews", report prepared for the Expert Panel on Skills. http://acst-ccst.gc.ca/skills

Scarpetta, S., A. Bassanini, D. Pilat, and P. Schreyer (2000), "Economic Growth in the OECD Area: Recent Trends at the Aggregate and Sectoral Level", OECD Economics Department Working Papers No. 248, June. http://www.oecd.org/eco/eco

Stager, D. (1999), "Labour Market Trends and Projections for Systems Analysts and Computer Programmers in Canada", RE-99-4E, Human Resources Development Canada. http://www.hrdcdrhc.gc.ca/arb/publications/research/1999docs/abr-99-4e.shtml

Statistics Denmark (2001), Information Society Denmark - A Statistical Mosaic, Copenhagen. 
Statistics Finland (1999), On the Road to the Finnish Information Society II, Helsinki.

Temple, J. (2000), "Growth Effects of Education and Social Capital in the OECD Countries", OECD Economics Department Working Papers No. 263, October. http://www.oecd.org/eco/eco

United States Bureau of Labor Statistics (BLS) (2001), Mass Layoff Statistics, March. http://stats.bls.gov/mlshome.htm

United States Bureau of Labor Statistics (BLS) (2002), National Employment Matrix, February. http://www.bls.gov/emp/home.htm

United States Council on Competitiveness (1998), Winning the Skills Race. http://www.compete.org

United States Department of Commerce (DOC) (1999), The Digital Workforce: Building Infotech Skills at the Speed of Innovation, Technology Administration, Office of Technology Policy, June. http://www.ta.doc.gov/otp/Reports.htm

United States Department of Commerce (2000a), The Digital Workforce: Update, Office of Technology Policy, August.

United States Department of Commerce (2000b), Digital Economy 2000, Economics and Statistics Administration, June. http://www.esa.doc.gov/de2k.htm

United States Department of Commerce (2002), Digital Economy 2002, Economics and Statistics Administration, February. http://www.esa.doc.gov/508/esa/DIGITALECONOMY2002.htm

United States Department of Commerce, US Department of Education, US Department of Labor, National Institute of Literacy, Small Business Administration (1999), $21^{\text {st }}$ Century Skills for $21^{\text {st }}$ Century Jobs, January. http://www.vpskillsummit.org

United States Immigration and Naturalization Service (INS) (2000a), "Characteristics of Specialty Occupation Workers (H-1B): October 1999 to February 2000", June. http://www.ins.gov

United States Immigration and Naturalization Service (INS) (2000b), "Leading Employers of Specialty Occupation Workers (H-1B): October 1999 to February 2000", June. http://www.ins.gov

United States National Research Council (NRC) (2001), Building a Workforce for the Information Economy, National Academy Press, Washington D.C: http://books.nap.edu/html/building_workforce/

United States National Science Foundation (NSF) (2000a), Science and Engineering Indicators 2000, National Science Board, Arlington VA. http://www.nsf.gov/sbe/srs/seind00/start.htm

United States National Science Foundation (NSF) (2000b), Women, Minorities and Persons with Disabilities in Science \& Engineering 2000, Arlington VA.

Weinstein, E. (1999), "How and Why Government, Universities and Industry Create Domestic Labor Shortages of Scientists and High-Tech Workers", National Bureau of Economic Research (NBER). http://nber.nber.org/ peat/PapersFolder/Papers/SG/NSF.html

Wilson, R. (2000), Skills Survey 2000, Institute of Directors (IoD), IoD Research Paper, London, November.

World Information Technology and Services Alliance (WITSA) (2001), WITSA Inventory on IT Skills and Workforce Initiatives, Interim Compilation, 3 April. 